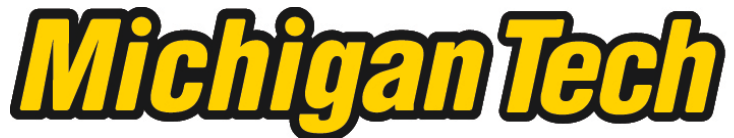 \\ Michigan Technological University Create the Future Digital Commons @ Michigan Tech
}

2010

Human and embodied energy analysis applied to water source protection and household water treatment interventions used in Mali, West Africa

R. Brendan Held

Michigan Technological University

Follow this and additional works at: https://digitalcommons.mtu.edu/etds

Part of the Civil and Environmental Engineering Commons

Copyright 2010 R. Brendan Held

\section{Recommended Citation}

Held, R. Brendan, "Human and embodied energy analysis applied to water source protection and household water treatment interventions used in Mali, West Africa ", Master's report, Michigan Technological University, 2010.

https://doi.org/10.37099/mtu.dc.etds/506

Follow this and additional works at: https://digitalcommons.mtu.edu/etds

3 Part of the Civil and Environmental Engineering Commons 


\title{
HUMAN AND EMBODIED ENERGY ANALYSIS APPLIED TO WATER SOURCE PROTECTION AND HOUSEHOLD WATER TREATMENT INTERVENTIONS USED IN MALI, WEST AFRICA
}

By

\author{
R. Brendan Held
}

\author{
A REPORT \\ Submitted in partial fulfillment of the requirements for the degree of \\ MASTER OF SCIENCE \\ in Environmental Engineering \\ MICHIGAN TECHNOLOGICAL UNIVERSITY \\ 2010 \\ (C) R. Brendan Held
}


This report, "Human and embodied energy analysis applied to water source protection and household water treatment interventions used in Mali, West Africa", is hereby approved in partial fulfillment of the requirements for the degree of master of science in environmental engineering.

Department of Civil and Environmental Engineering

\section{Signatures:}

\section{Report Advisor}

James R. Mihelcic

Department Chair

William Bulleit

Date 


\section{TABLE OF CONTENTS}

LIST OF TABLES iv

LIST OF FIGURES v v

ABSTRACT vii

1 INTRODUCTION 1

2 LITERATURE REVIEW 2

2.1 Debate over point of use water treatment versus water source protection 2

2.2 Embodied Energy and other metrics as sustainability indicators 5

$\begin{array}{ll}2.3 \text { The importance of human energy } & 6\end{array}$

3 OBJECTIVES AND HYPOTHESES 8

4 METHODS 9

4.1 Study setting and functional unit 9

4.2 Input-output analysis and embodied energy 11

4.3 I/O-based models, process-based models and the case of cement 18

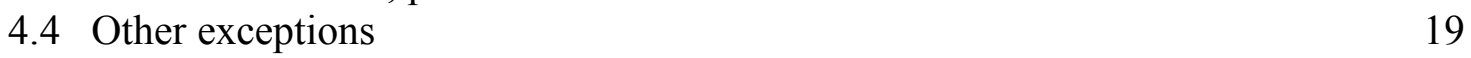

4.5 Human energy calculations 19

4.6 Human energy expended collecting water 23

4.7 The interventions $\quad 25$

$\begin{array}{lll}\text { 4.7.1 Source protection interventions } & 25\end{array}$

4.7.2 Point of use interventions 31

5 RESULTS AND DISCUSSION 36

5.1 Embodied energy of point of use water treatment vs. water source protection 37

5.2 Human energy as a social sustainability indicator 40

$\begin{array}{ll}5.3 \text { Balancing human and material energy } & 42\end{array}$

5.4 Qualifying assumptions and simplifications 43

6 CONCLUSIONS $\quad 46$

7 RECOMMENDATIONS FOR FURTHER STUDY 47

8 WORKS CITED $\quad 48$

APPENDIX A: LEONTIEF INVERSE MATRIX FOR THE MALIAN ECONOMY, $2006 \quad 54$

APPENDIX B: MATERIALS LISTS, I/O MODELS FOR EACH INTERVENTION55

APPENDIX C: LIST OF HUMAN ENERGY EXPENDED CONSTRUCTING AND $\begin{array}{lr}\text { OPERATING INTERVENTIONS } & 60\end{array}$ 


\section{LIST OF TABLES}

Table 1: Reduction in diarrheal diseases by intervention type ................................... 3

Table 2: Eight interventions evaluated in this study according to level of labor and

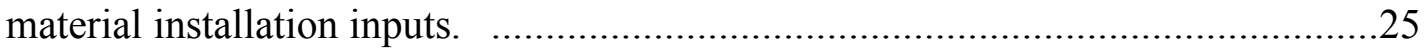

Table 3: Total embodied energy of eight interventions over a ten-year time frame .........37

Table 5: Percentage of human energy performed by women ..................................41

Table 6: Evaluated energy savings of source protection interventions ..........................43

Table 7: Embodied energy of 1 tonne of cement by source and model .........................43

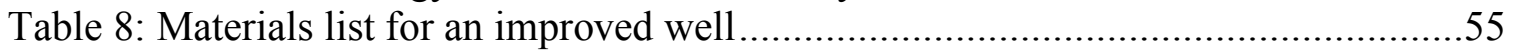

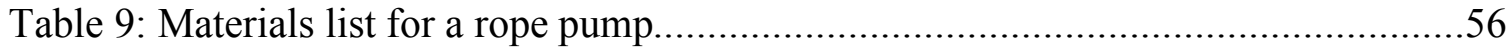

Table 10: Materials list for an India Mark II hand pump ....................................57

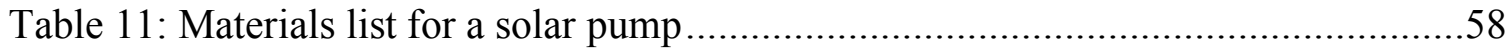

Table 12: Materials list for a biosand filter...........................................................59

Table 13: Materials list for a ceramic filter. Replaced once over 10 years .....................59

Table 14: Materials list for chlorination. Bottle purchased 335 times over 10 years........59

Table 15: Materials list for boiling. Quantity calculated over 10 years ........................59

Table 16: Human energy expended constructing and using an improved well ...............60

Table 17: Human energy expended constructing and using a rope pump ......................61

Table 18: Human energy expended constructing and using an India Mark II pump .......62

Table 19: Human energy expended constructing and using a solar pump .....................62

Table 20: Human energy expended constructing and using a biosand filter ..................63

Table 21: Human energy expended using a ceramic filter ....................................63

Table 22: Human energy expended using chlorine bleach ......................................64

Table 23: Human energy expended using firewood to boil water ...............................65 


\section{LIST OF FIGURES}

Figure 1: Recommended expansion path of water quality interventions....................... 4

Figure 2: The decision-making framework used in this study to calculate the embodied energy of a material ...................................................................... 15

Figure 3: Average PARs for males performing various activities, and PAR category

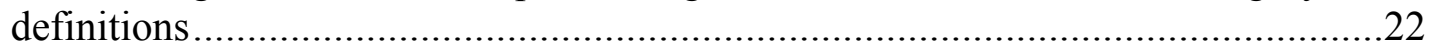

Figure 4: Flowchart summarizing human energy calculations used in this study ...........23

Figure 5: Photo of a rope pump installation, apron not shown ................................28

Figure 6: Photograph of the India Mark II hand pump............................................29

Figure 7: Sketch of a typical biosand filter ................................................................34

Figure 8: A sketch of the type of ceramic filter promoted by Potters for Peace...............35

Figure 9: Total embodied energy of selected interventions .........................................39

Figure 10: Percentage of Total Embodied Energy Expended by Humans ......................39 


\section{ACKNOWLEDGMENTS}

I'd like to thank the following people and institutions that were instrumental in the completion of this project:

Michigan Technological University, the United States Peace Corps, and the University of South Florida

My advisor and committee members, James Mihelcic Blair Orr, and Brian Barkdoll

My mentors Qiong Zhang, Michael MacCarthy, and Weiwei Mo

The staff of Peace Corps Mali and Peace Corps Madagascar, particularly

Michael Simsik, Haoua Traore, Adama Bagayoko and Alyssa Karp

The staffs of Ny Tanintsika, BushProof, USAID, and WaterAid

Massa Coulibaly, Luc Savard, Kaira Wagoner

My supportive and understanding friends and families everywhere.

Thank you. 


\begin{abstract}
As water quality interventions are scaled up to meet the Millennium Development Goal of halving the proportion of the population without access to safe drinking water by 2015 , there has been much discussion on the merits of household- and source-level interventions. This study furthers the discussion by examining specific interventions through the use of embodied human and material energy. Embodied energy quantifies the total energy required to produce and use an intervention, including all upstream energy transactions. This model uses material quantities and prices to calculate embodied energy using national economic input/output-based models from China, the United States and Mali. Embodied energy is a measure of aggregate environmental impacts of the interventions. Human energy quantifies the caloric expenditure associated with the installation and operation of an intervention is calculated using the physical activity ratios (PARs) and basal metabolic rates (BMRs). Human energy is a measure of aggregate social impacts of an intervention.
\end{abstract}

A total of four household treatment interventions - biosand filtration, chlorination, ceramic filtration and boiling - and four water source-level interventions - an improved well, a rope pump, a hand pump and a solar pump - are evaluated in the context of Mali, West Africa. Source-level interventions slightly out-perform household-level interventions in terms of having less total embodied energy. Human energy, typically assumed to be a negligible portion of total embodied energy, is shown to be significant to all eight interventions, and contributing over half of total embodied energy in four of the interventions. Traditional gender roles in Mali dictate the types of work performed by 
men and women. When the human energy is disaggregated by gender, it is seen that women perform over $99 \%$ of the work associated with seven of the eight interventions. This has profound implications for gender equality in the context of water quality interventions, and may justify investment in interventions that reduce human energy burdens. 


\section{INTRODUCTION}

On a global level, significant progress has been made in water and sanitation coverage since the adoption of the United Nations Millennium Declaration in the year 2000. Current trends suggest that the Millennium Development Goal of halving the proportion of the population without sustainable access to safe drinking water will be met or exceeded by 2015 . However, not as much success has been witnessed on a regional level. For example, between 1990 and 2008, the proportion of the population in Sub-Saharan Africa without access to an improved water source has decreased by only $20 \%$, which leaves an estimated $40 \%$ of the population without access. In rural areas, coverage is even sparser. As of 2008 , only $47 \%$ of rural populations in Sub-Saharan Africa have access to improved water sources. Additionally, many challenges remain in improving sanitation coverage, with an estimated 1.1 billion people practicing open defecation. Again, less than half of urban populations and only $24 \%$ of rural populations in Sub-Saharan Africa are using improved sanitation facilities (United Nations, 2010).

Some critics suggest that even the measured gains should be met with skepticism, suggesting that real progress is more difficult to measure. It has been pointed out that some water sources that meet the criteria to be considered an improved source are actually insufficient for protecting against waterborne diseases, particularly diarrhea. For example, many improved sources, such as centralized systems in urban areas of less developed countries (LDCs), do not function effectively to achieve desired 
results (Zérah, 2000; Kyessi, 2005; Basu and Main, 2001; and Peter-Varbenets et al., 2009). Likewise, decentralized small-scale systems in rural areas, such as improved wells and hand pumps, have also been shown to be prone to recontamination between collection and consumption (Clasen and Bastable, 2003). To put it simply, some interventions have worked and some have not.

Researchers and policy makers are devoting much attention to determining which interventions have been the most effective and which ones are suitable for scaling up in the effort to close the remaining coverage gap. For example, Clasen et al. (2007) used cost-effective analysis as an economic sustainability metric to evaluate several water quality interventions. The present study uses the context of subsistence farming communities in rural Mali to contribute two new metrics for this same purpose: Total embodied energy as an environmental sustainability metric and human energy as a social sustainability metric.

\section{LITERATURE REVIEW}

\subsection{Debate over point of use water treatment versus water source protection}

Esrey et al. (1985), Esrey et al. (1991), and Esrey (1996) performed meta-analyses of water, sanitation and hygiene interventions. The results implied that water quality interventions alone did not reduce diarrhea morbidity as effectively as sanitation or hygiene improvements alone. For example, the multi-country study from 1991 found the results shown in Table 1, showing that among rigorous studies, interventions focusing exclusively on water quality are the least effective of all. 
Table 1: Reduction in diarrheal diseases by intervention type

\begin{tabular}{|l|cc|cc|}
\hline \multirow{2}{*}{ Route } & \multicolumn{2}{|c|}{ All Studies } & \multicolumn{2}{c|}{ Rigorous Studies } \\
\cline { 2 - 5 } & $\begin{array}{c}\text { No. of } \\
\text { studies }\end{array}$ & Reduction & No. of Studies & Reduction \\
\hline Water and Sanitation & 7 & $30 \%$ & 2 & $30 \%$ \\
Sanitation & 11 & & 5 & $36 \%$ \\
Water Quality and Quantity & 22 & $16 \%$ & 2 & $17 \%$ \\
Water Quality & 7 & $17 \%$ & 4 & $15 \%$ \\
Water Quantity & 7 & $27 \%$ & 5 & $20 \%$ \\
Hygiene & 6 & $33 \%$ & 6 & $33 \%$ \\
\hline
\end{tabular}

Courtesy of Thomas Clasen, London School of Hygiene and Tropical Medicine

Clasen and Cairncross (2004) pointed out that the Esrey studies had focused on source protection interventions to the exclusion of water quality interventions at the household level. Their meta-analysis investigated the impacts of water quality interventions focused on household water treatment and storage (HWT) and found significant reductions in the risk of diarrhea. No comparison was made with hygiene and sanitation interventions, nor did the study examine the impact of the interventions on water-washed diseases. Clasen et al. (2007) also performed a meta-analysis to compare the cost-effectiveness of several water quality interventions, including HWT and source improvement, culminating in a recommended path of expansion for intervention programs, shown in Figure 1. The expansion path recommends the most cost-effective order in which to implement the interventions based on incremental cost-effective analysis. Their results further underscored that source protection and HWT interventions should not be considered as equivalent when evaluating the 
effectiveness of water quality interventions, and so the conclusions drawn by Esrey may be over-simplified.

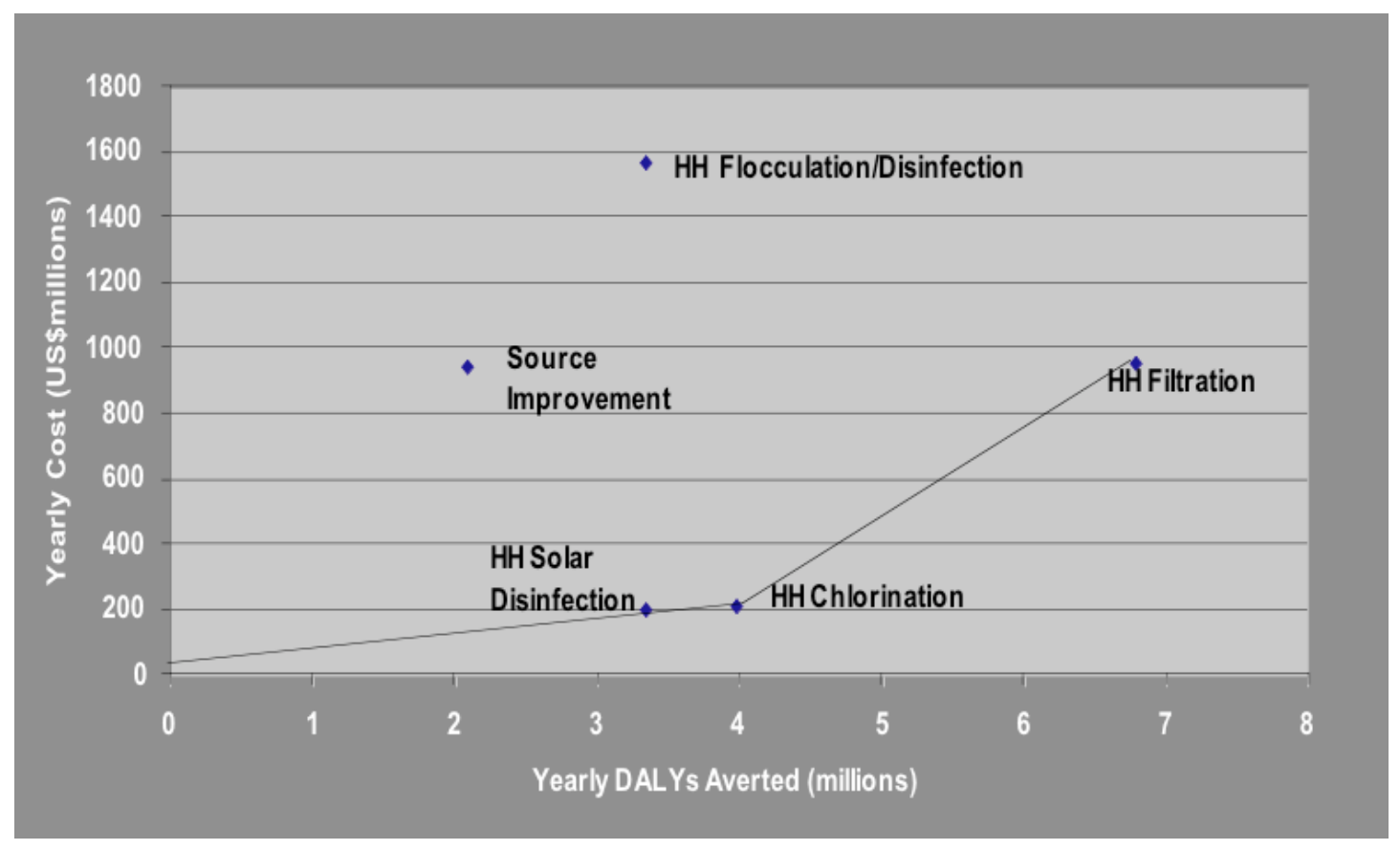

Figure 1: Recommended expansion path of water quality interventions (from Clasen, 2008)

Schmidt and Cairncross (2009) opined that the evidence to date does not conclusively support scaling up household water treatment (HWT) interventions, as the results reported in meta-analyses may be due to varying degrees of efficacy of the HWT technologies studied, as well as publication bias or conflict of interest. Clasen et al. (2009) disagreed; pointing out that bias can only account for a portion of the risk reduction, and suggesting that policy makers need not wait for perfect knowledge before taking action. However, subsequent studies have had difficulty demonstrating the effectiveness of HWT interventions in environments with poor sanitation (Sthreshley et al., 2010; and Berhanu et al., 2009). 
With both source protection and HWT unable to conclusively reduce the risk of diarrhea in unsanitary environments such as rural Sub-Saharan Africa, it makes good sense to consider other indicators when deciding which types of water quality interventions fit the overall needs of a community. This report uses embodied energy and human energy as new metrics by which to compare a total of eight interventions at the source and household scale.

\subsection{Embodied Energy and other metrics as sustainability indicators}

Though water access is listed in the environment section of the Millennium Development Goals, the focus of much of the literature on this topic suggests that drinking water access is less related to biodiversity conservation and deforestation than it is to health outcomes and social acceptability. However, when water access is examined within a life-cycle framework, these broader environmental impacts become more apparent.

Embodied energy is one tool for examining these broader impacts. Embodied energy seeks to evaluate products and services by quantifying the total energy consumed during the life of the product or service. This includes upstream energy used during the extraction, processing, manufacture and transportation of materials, as well as use energy required to operate and maintain the product or service. Embodied energy has been used in a wide range of applications in industrialized countries including evaluating residential buildings, office buildings, iron and steel products (Lenzen and Dey, 2000), concrete, wood (Lenzen and Treloar, 2002), food (Coley and Goodliffe, 
1998), water treatment plants (Mo et al., 2010) and water supply systems (Stokes and Horvath, 2006).

As securing an affordable and reliable source of energy is becoming a priority for many economies, embodied energy is becoming more widely used as a sustainability indicator. Moreover, energy consumption is often associated with combustion of fossil fuels, which is associated with greenhouse gas emissions, acid rain, and environmental degradation due to the extraction of the fuel. Effects of energy consumption from renewable sources are also known to include deforestation, habitat loss and production of radioactive waste. It is generally thought that if less energy is consumed during the life cycle of a product, then there are fewer environmental costs associated with the product (Center for Sustainable Systems, 2009).

While transitioning economies have seen some application of embodied energy analysis (Hong et al., 2007) there has been little to no analysis of products in less developed countries (LDCs). Yet, as is shown in the current report, the EE of smallscale water quality interventions in developing countries can be significant, especially as implementation of these technologies is scaled up to meet demand at a global level.

\subsection{The importance of human energy}

In addition to the energy required to produce and maintain the materials that go into an intervention, there is also an element of human energy required to install, use, and maintain the intervention. Examples of this human energy would be the work 
required to lift a bucketful of water from a well, the work required to haul and sift sand and gravel for the concrete, or the energy expended chopping and collecting firewood used to disinfect the water by boiling. This human energy is typically assumed to be a negligible portion of the total embodied energy, so it is often left outside the scope of many studies. The current report shows that human energy is a significant component of the total embodied energy of water quality interventions at both the source and household levels.

Subsistence farmers live on a tight energy budget. The Food and Agriculture Organization (Food and Agriculture Organization, 2001) estimates that a 70-kg male with a "vigorously active lifestyle" - i.e. including six or more hours of nonmechanized agricultural work - expends $16.42 \mathrm{MJ}(3,925 \mathrm{kcal})$ every day. Millet, the staple food of rural farmers in Mali, is a low-yield and calorie-poor food, yielding only $3.8 \mathrm{MJ} / \mathrm{kg}$ and $600 \mathrm{~kg} /$ hectare. For comparison, rice yields $8.2-13.3 \mathrm{MJ} / \mathrm{kg}$ and up to $2,500 \mathrm{~kg} /$ hectare (Fraenkel, 1986). By this estimation, two such individuals eating little more than millet would need to farm five hectares between them to meet their caloric needs for the year. This is a rough calculation, but it serves to show that human energy should not be treated as a trivial input to any subsistence farming community system.

Many development organizations require communities to contribute a portion of the project cost as a way to ensure that the community has the means and incentive to sustain the project into the future. But because the resources in rural farming 
communities tend not to be very liquid, this contribution is met with in-kind labor. In fact, appropriate technologies are often designed with the intent of utilizing labor inputs and minimizing material inputs. But the fact that human energy is widely available does not make it cheap. It is estimated that a healthy man can generate a sustained 60-75 Watts of power over the course of an 8-hour workday (Hofkes, 1987). Even at a modest salary of $\$ 2.12 /$ day $(1,000 \mathrm{FCFA} /$ day $)$, which is a typical valuation of unskilled labor for in-kind contributions within project planning frameworks, this amounts to $\$ 3.54 / \mathrm{kWh}$. For comparison, electric utilities in the United States charge about $\$ 0.10 / \mathrm{kWh}$.

The above analysis suggests that though human energy may not be a significant fraction of the total embodied energy of a water quality intervention, it is scarce and expensive for the users of the intervention. The present report investigates the lifecycle human energy expended by the users as a social metric for measuring the sustainability of a water quality intervention.

\section{OBJECTIVES AND HYPOTHESES}

The objective of this study is to demonstrate a means to analyze the environmental and social impacts of water quality interventions as they are scaled up to provide coverage to the 4.5 million rural Malians currently without access to a functioning improved source (Sutton, 2010). Though these interventions are typically designed to do more with less, the aggregate effect at a regional or global scale can be expected to be quite large. There have been studies with an eye to an aggregate economic effect 
of implementing source improvement of a water supply or point of use water treatment. For example, (Clasen et al., 2007) look at the cost effectiveness of a number of interventions on the basis of disability-adjusted life years (DALYs) averted. This study seeks to augment those studies by examining aggregate environmental effects through embodied energy and aggregate social effects through human energy. The following hypotheses are tested:

1) Embodied energy is dependent on the scale of the intervention - that is, a household level intervention as opposed to an intervention at the source.

2) The human energy required to install and operate an intervention is small relative to embodied energy, but can be a significant portion of the energy budget of a subsistence farmer.

\section{METHODS}

\subsection{Study setting and functional unit}

This study uses rural subsistence farming communities in Mali as the setting in which water quality interventions are implemented. The author has lived and worked in Africa on water supply and sanitation systems for two years as part of his Peace Corps service and in such a setting in Mali for 17 months, and has directly experienced several of the chosen interventions.

The Direction Nationale Hydraulique du Mali (DNH) defines a village as rural settlement with less than 2,000 inhabitants. The average population of these villages is 600 (Direction Nationale Hydraulique, 2004). The DNH also defines basic water 
access as 20 liters per capita per day with a source capacity of at least 8 cubic meters per day, and with no more than 400 water users per source (Direction Nationale Hydraulique, 2004). Based on these criteria, this study uses a functional unit of 12 cubic meters per day, enough water to serve a village of 600 inhabitants, for a tenyear time frame. The selection of a ten-year time frame is consistent with professional expectations of the lifetimes of the selected interventions (MacCarthy, 2010). It is also a conservative interpretation of the Millennium Development Goals, which implicitly defines project lifetimes of 15 years - why implement an intervention in the year 2000 if it is expected to expire before progress is measured in 2015? An exception is made in the case of the ceramic filters, which are recommended for replacement after five years by the manufacturer (Campbell, 2005). For this reason, filters are assumed to be replaced once within the ten-year period.

In rural Mali, groundwater wells are an important part of family life. Most families will have a well within or near their property. Often, the first step in building on a new property is to dig the well (Peace Corps Mali, 2009). Surface waters supply an estimated $5 \%$ of the population, but the vast majority of Malians use groundwater (DHS, 2006).

Traditional wells in Mali are typically hand-dug to a diameter of about 1 meter. The top of the well is covered with logs, stones, and earth, with a small opening for water to be collected using a rope and bucket. Water levels are typically $10-25 \mathrm{~m}$ below ground surface. (United Nations, 1998) It is assumed as a baseline condition for this 
study that there is an existing traditional well within 75 meters of the household with a water table $20 \mathrm{~m}$ below ground surface. Interventions are individually described with their associated assumptions in Section 4.7.

\subsection{Input-output analysis and embodied energy}

Input-output (I/O) analysis is a method by which the structure of an economy can be used to estimate the economic output required to sustain a given economic activity. In some cases the required energy resources and resultant pollution associated with those economic activities can also be estimated. The methodology in this study closely follows the one outlined by Carnegie Mellon's EIO-LCA website (Carnegie Mellon University Green Design Institute, 2010).

The Carnegie Mellon EIO-LCA method uses an $n \times n$ input-output matrix, A, to model an economy with $n$ sectors, where element $a_{i j}$ of the matrix represents the amount of direct input from sector $i$ required to produce a dollar of output from sector $j$. If there is a demand for goods from each sector of the economy, given by a vector, $\mathbf{y}$, where $y_{i}$ is the demand from sector $i$, then the output of the economy, $\mathbf{x}_{\text {direct }}$, is given by $(\mathbf{I}+\mathbf{A}) \mathbf{y}$. This first-tier output also creates additional demand of goods from second-tier suppliers, a vector equal to the product AAy. The sum of outputs from all suppliers is then the infinite series $(\mathbf{I}+\mathbf{A}+\mathbf{A A}+\mathbf{A A A}+\ldots)$. The Leontief inverse matrix, given by $(\mathbf{I}-\mathbf{A})^{-1}$ can be shown to be equivalent to this series. The elements of the Leontief inverse matrix, $a_{i j}$, therefore represent the total inputs from sector $i$ required to produce a dollar of sector $j$, including every upstream transaction along 
the supply chain. The Leontief inverse matrix is also sometimes called the total requirements matrix.

In industrialized economies, and in some transition economies, there are transformation matrices that can be applied to the model, allowing the calculation of resource inputs such as energy or water, or external outputs like greenhouse gases, required per unit economic output of a given sector. This means that the embodied energy of a particular intervention can be calculated by assigning its component parts to an economic sector, and by multiplying the appropriate element of the total energy requirement matrix by the cost of the component.

Because many products are manufactured and processed in countries other than the one in which they are consumed, $\mathrm{I} / \mathrm{O}$ analysis faces many challenges in a global economy, particularly in less developed countries (LDCs). Detailed and disaggregated economic data are difficult to obtain for LDCs, and presents a major challenge to applying $\mathrm{I} / \mathrm{O}$ analysis to their economies. This study approaches this challenge by acknowledging that Mali is primarily an agrarian economy, and thus imports account for many of its manufactured goods. It is true in some cases that a product may be manufactured domestically or within West Africa, but many of the most energy intensive upstream processes occur in other countries. For example, the Nigerian company Duraplast manufactures PVC pipe, but the PVC resin is imported from elsewhere (MacCarthy, 2010). The energy required to extract and refine the raw materials necessary to produce PVC resin is thought to be much greater than the 
energy required to extrude the resin into products like PVC pipes. If these steps do not take place within Niger, then the Nigerian I/O model does not account for the energy consumed by these steps. In these cases, I/O analysis was performed using economic data from countries thought to best represent the most likely supplier country.

The Carnegie Mellon EIO-LCA website provides three economic input/output matrices with energy transformation matrices: Canada, China, and the United States. To this author's knowledge, no such matrix is available for Mali or for other countries in West Africa. Import data for Mali (International Trade Centre, 2010) were used to determine which matrix was most appropriate for each commodity. For example 42 of the 83 products imported by the Malian iron and steel sector come from China, and the value of these imports is growing by $43 \%$ per annum, so China was used as the country of origin.

In the case of PVC products, it was noted that of the countries exporting plastic products to Mali, Senegal is the country exporting the most primary polymers of vinyl chloride and other halogenated olefins. Senegal, in turn, imports most if its plastic products from France, which exported $\$ 1.2$ billion of PVC in 2008 (International Trade Centre, 2010). Since no available European I/O model includes energy effects, another nation had to be selected. The EIO-LCA website includes an economic activity I/O model for Spain, a member of the European Union adjacent to France. This model was used to compare the economic activity required for Spain to produce 
a unit of economic output from the rubber and plastic sector with those of China, Canada and the United States (Carnegie Mellon University Green Design Institute 2008a, 2008b, 2008c, 2008d). The Spanish model indicated that 2.73 euros of economic activity were required to produce 1 euro of output from the rubber and plastic sector. The United States also required 2.73 dollars of economic activity for 1 dollar of output from the sector of plastics pipe and pipe fitting manufacturing. As both Spain and the United States are industrialized countries and produce similar economic activities per unit output of plastic, it was assumed that the embodied energies for these sectors would also be equivalent, and thus the United States' I/O model was used to quantify the embodied energy of PVC products. The use of different tables for different products introduces uncertainty into the model, but it is not possible to quantify this uncertainty. Figure 2 shows the decision-making framework used in this study to calculate the embodied energy of a material. 


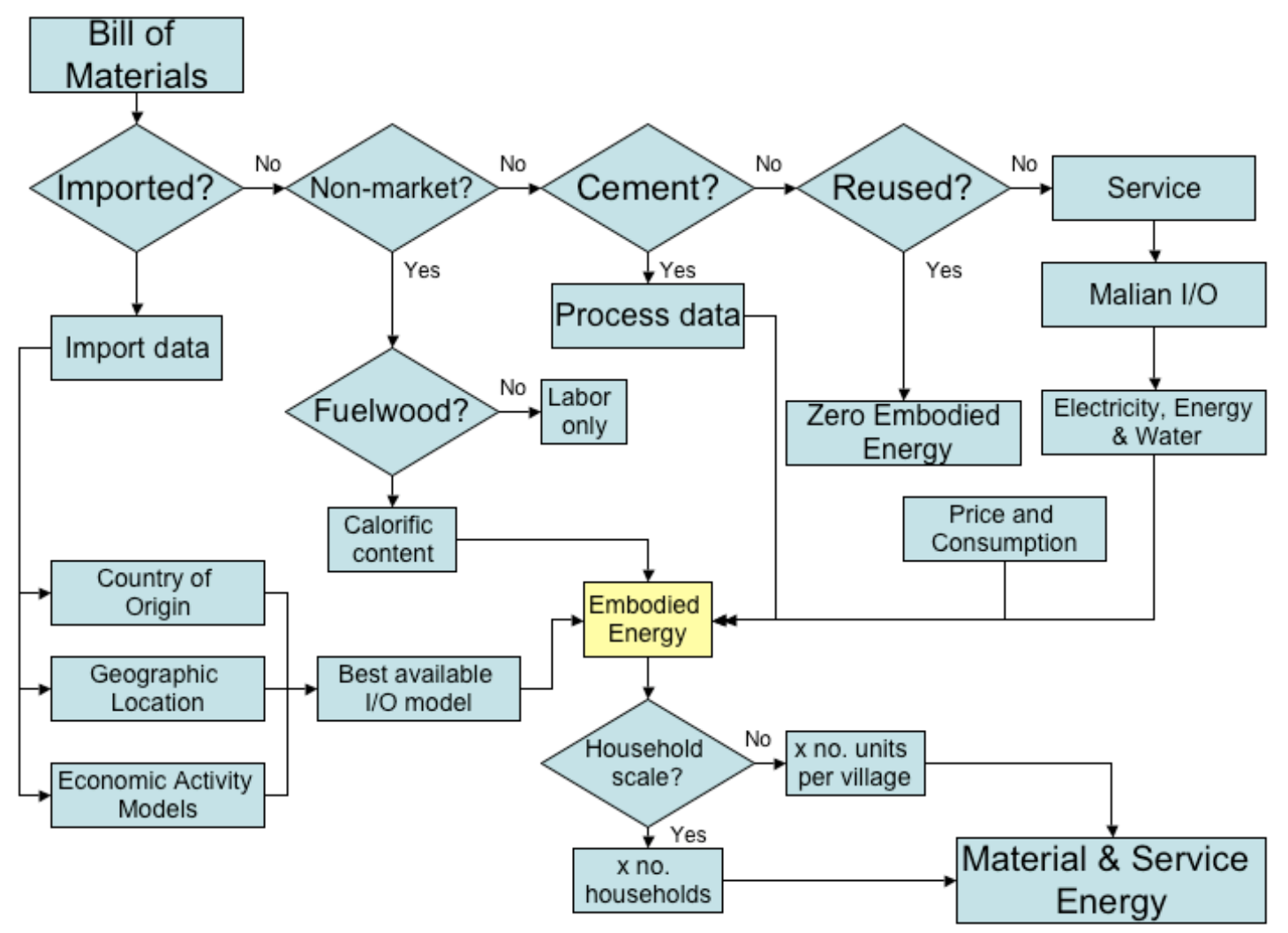

Figure 2: The decision-making framework used in this study to calculate the embodied energy of a material

The energy costs of transportation to Mali could not be calculated exactly as the weights of specific components were not known. A rough estimate was generated to determine if transportation energy could be significant in the analysis. This estimate is based on the length of the most used shipping lanes as estimated from Halpern et al. (2008). Energy and emissions data for diesel powered sea freight reported by carbonfund.org (2010) and the energy content of diesel fuel reported by Oak Ridge National Laboratories (2010) were used to calculate the total energy for transportation. The test case used for the estimate was based on a sea freight shipment of $100 \mathrm{~kg}$ over a distance of $18,600 \mathrm{~km}$, the estimated distance from a port in southeast China to Dakar, Senegal. The energy required for overland transportation 
from Dakar to the village is excluded from the model, because the distance is minor compared to global shipping, and it is likely to include several mechanical and nonmechanical modes of transport.

For products and services produced domestically in Mali, or regionally in West Africa, a different method was used. This is the case with cement, which is extracted and processed from cradle to gate in Mali and Senegal, and also the borehole drilling performed as part of solar pump and hand pump installations. In these instances, the model used is based on a highly aggregated use table for the Malian economy, which was obtained from Groupe de Recherche en Économie Appliquée et Théorique (GREAT, 2010).

The first step in adapting the Malian table for use was to create a Leontief inverse matrix. It was assumed that each sector produces only one product - that is, no secondary products are produced. Mathematically speaking, this means that the Malian make table is the identity matrix. A symmetric commodity-by-commodity matrix was then created by multiplying the use table by the make table. Next, dividing each element, $a_{i j}$, by the sum of column $j$, created the direct coefficient matrix. The Leonteif inverse was then calculated using the steps outlined at the beginning of this section. A translated version is reproduced in Appendix A. 
Next, it was necessary to devise a method for disaggregating the energy, electricity and water (EEW) sector so that the inputs from water portion of this sector did not get counted in the embodied energy estimations. To do this at a matrix level is difficult because, in Mali, the same utility company, Energy du Mali (EDM), monopolizes all three products. This prohibits the use of a transformation matrix to calculate the flow of energy between sectors at every stage of production. So rather than create separate sectors for each commodity, the total economic activity from the EEW sector was calculated using the Leonteif inverse matrix and subsequently separated into component outputs. This transformation was accomplished by using consumption estimates and the price of electricity and water from a utility bill. The embodied energy of a service or product was then be calculated as:

$$
\begin{gathered}
\text { Embodied Material Energy }(\mathrm{GJ})= \\
(\text { Price of Input }(\$)) \times\left(\frac{\text { Output of EEW Sector }(\$)}{\text { Demand of Input Sector }(\$)}\right) \times\left(\frac{\text { Energy and Electricty Revenue }(\$)}{\text { Output of EEW Sector }(\$)}\right) \times \\
\left(\frac{\text { Annual Energy Consumption }(\mathrm{GJ})}{\text { Gross Domestic Product }(\$)}\right) \times(\# \text { of units per village })
\end{gathered}
$$

The revenue generated from energy and electricity was calculated using the rates charged by EDM and the total reported electricity consumption (Central Intelligence Agency, 2010) and total reported water consumption (DNH, 2004). EDM charges for electricity and water using a progressive rate structure, increasing the rate as consumption increases. This study selected the lowest rate to be conservative. The annual energy consumption was taken from Direction Nationale de l'Energie (2007) and the gross domestic product was taken from Central Intelligence Agency (2010). 


\subsection{I/O-based models, process-based models and the case of cement}

I/O-based life cycle assessment (LCA) was devised as a way to correct for the truncation errors common in process-based LCA, which are typically introduced by conservative system boundary definitions. One of the inherent weaknesses of I/O models is the sacrifice of precision for the sake of completeness. Highly aggregated I/O tables are especially susceptible to this kind of error. Hybrid methodologies have been devised to alleviate this, typically by substituting process energy data into upstream energy paths (Suh and Huppes, 2005; Treloar et al., 2001).

To be consistent with the methodology described in the previous section, calculating the embodied energy of cement that is manufactured domestically or imported from Senegal would require assigning cement production to the other manufactured goods sector of the Malian I/O table. According to this model, the production of a metric ton of cement requires $89.5 \mathrm{MJ}$ of energy, far less than published process-based values of 3,200-6,300 MJ per metric ton (Boesch and Hellweg, 2010). This discrepancy is likely due to the fact that the other manufactured goods sector includes many products (e.g., soap, bleach, or simple tools) most of which are likely to be far less energy intensive to produce than cement. When the make table is assumed to be the identity matrix, cement is then considered equivalent to a hypothetical average product of the sector. In this case, process-based data are preferred to I/O-based data for the embodied energy calculation. 


\subsection{Other exceptions}

A number of component materials used in the interventions chosen for this study are non-market goods. Examples include gravel and sand collected by community members for making concrete, or firewood gathered locally and used to boil water. In the case of sand and gravel, only the human energy used to collect and sift the material is considered in the analysis, whereas in the case of firewood, the energy to collect the wood is considered, as well as the energy released upon combustion. Other exceptions were made as noted under the description of each intervention at the end of this section. Appendix B gives a complete list of material inputs for each intervention, as well as the associated I/O models and economic sectors.

\subsection{Human energy calculations}

Human energy calculations are based on information published on human energy requirements by the Food and Agriculture Organization. The caloric expenditure of a given activity will vary between individuals, but it can be correlated with many factors such as sex, age, weight and lifestyle. The first step to calculating the caloric expenditure of an activity is to estimate the individual's basal metabolic rate (BMR). This is the energy expended while maintaining the body's most essential functions (e.g., cell function and replacement, maintenance of body temperature, brain function, respiration and cardiac function) but not including functions such as the metabolic response to food. An individual's BMR is measured under standard conditions that include "being awake in the supine position after ten to 12 hours of fasting and eight hours of physical rest, and being in a state of mental relaxation in an ambient 
environmental temperature that does not elicit heat-generating or heat-dissipating processes" (Food and Agriculture Organization, 2001). This is essentially energy that the body will consume regardless of the activity. It will be subtracted from the total energy consumed by constructing and operating an intervention as described later in this section.

Rather than replicating the BMR conditions and measure the BMR of Malian subsistence farmers directly, this study used FAO-provided predictive equations based on sex, age and weight to estimate BMR. For example, the predictive equation for an 18-30 year old male is:

$$
\mathrm{BMR}=0.063 * W+2.896
$$

where BMR is measured in $\mathrm{MJ} / \mathrm{day}$ and $W$ is the body mass in $\mathrm{kg}$. If the male weighs $70 \mathrm{~kg}$, then his BMR is $7.306 \mathrm{MJ} / \mathrm{d}(1,746 \mathrm{kcal} / \mathrm{d})$. To account for lifestyle, the FAO uses a physical activity level (PAL), expressed as a multiple of BMR, to classify the energy requirements of various lifestyles. In the case of a vigorously active lifestyle that is characterized by non-mechanized labor - and contrasted with a moderately active lifestyle that is characterized by low-intensity aerobic activities like waiting tables or arranging merchandise - the PAL is 2.25 . This means that the total energy expenditure (TEE) of $70 \mathrm{~kg}$ male is $16.4 \mathrm{MJ} / \mathrm{d}$, or $3,929 \mathrm{kcal} / \mathrm{d}$. This is the baseline individual energy requirement used as a reference for this study.

A physical activity ratio (PAR) is the energy required for a specific activity, expressed as a multiple of BMR. The FAO report (Food and Agriculture 
Organization, 2001) compiled results from a number of studies of PARs of various activities. Because BMR is a essentially a sunk cost of a living person, it was excluded from the energy cost of a given activity by subtracting a unit value from the PAR. In general, the energy expended performing a given activity was calculated as:

$$
\begin{aligned}
& \text { Embodied Human Energy }(\mathrm{MJ})= \\
& (\text { PAR }-1) \times\left(\text { BMR }\left(\frac{\mathrm{MJ}}{\mathrm{hr}}\right)\right) \times(\text { Hours per Day }) \times(\text { Days Labor is Performed }) \\
& \times(\text { Laborers per Household }) \times(\# \text { of Households })
\end{aligned}
$$

When possible, human energy expended by the users during the installation and operation of the water supply and point of use interventions was calculated using the FAO-reported PARs. Figure 3 shows the PAR of all activities reported by the FAO in ascending order. Some activities are highlighted and labeled for reference. In some cases, a work activity (e.g., collecting sand) did not have an exact match among the FAO-reported PARs. In these cases, the PAR of an analogous FAO-reported activity (e.g., shoveling) was used for the calculation. In other cases, no analogous FAOreported activity seemed appropriate, and the work activity was assigned to one of four activity categories. To define the PAR of an activity category, FAO-reported activities were ranked according to PAR and grouped into quartiles. The PAR of each quartile is the median PAR of the quartile. This is also shown in Figure 3. 


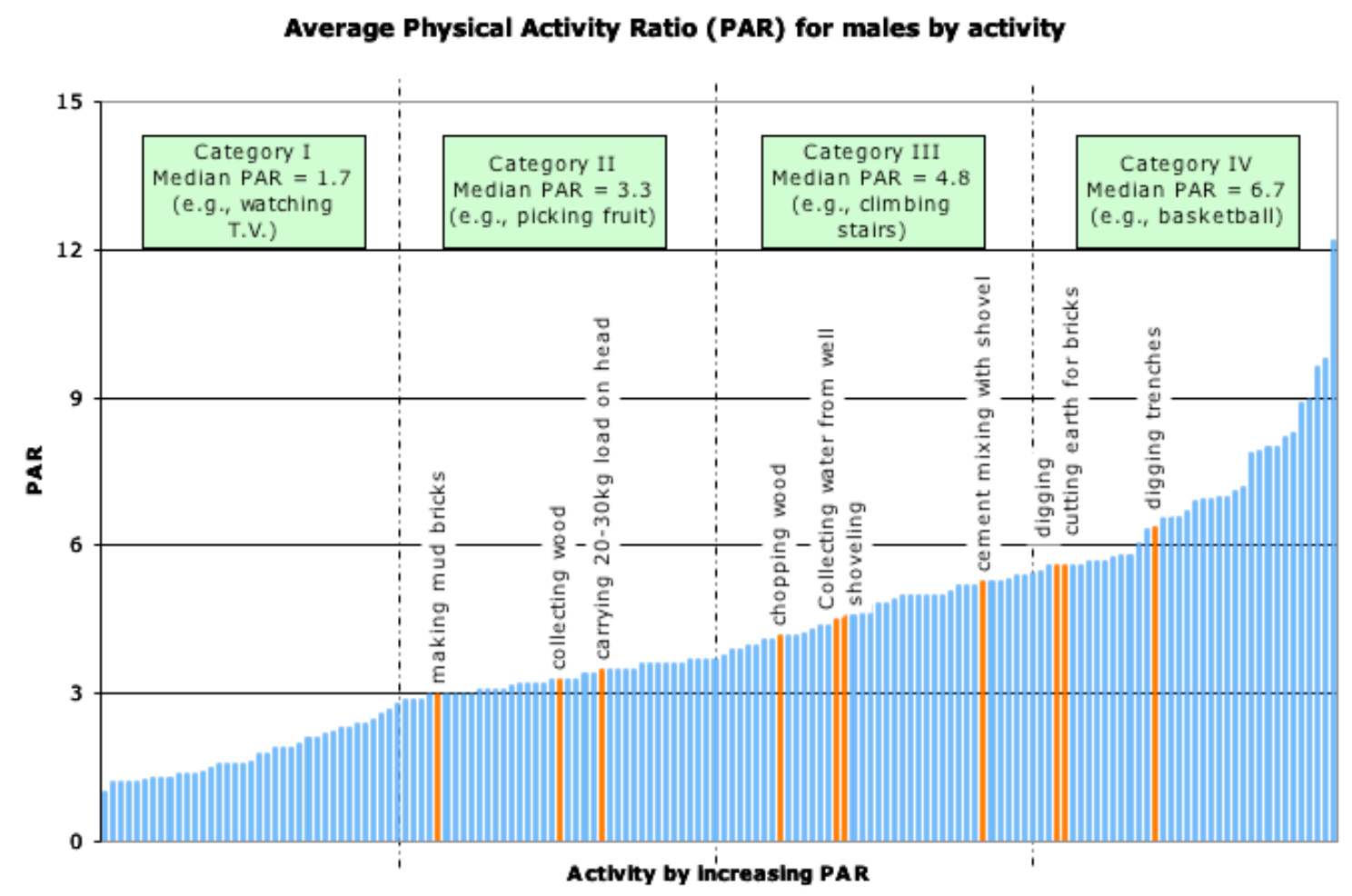

Figure 3: Average PARs for males performing various activities, and PAR category definitions (based on FAO, 2001)

The human energy required to use different types of pumps was computed using the documented input power and flow rates of the pumps as described in the next section. Figure 4 shows a flowchart summarizing how data sources were selected for this step. See Appendix $\mathrm{C}$ for a complete list of activities associated with each intervention, as well as the associated PARs. 


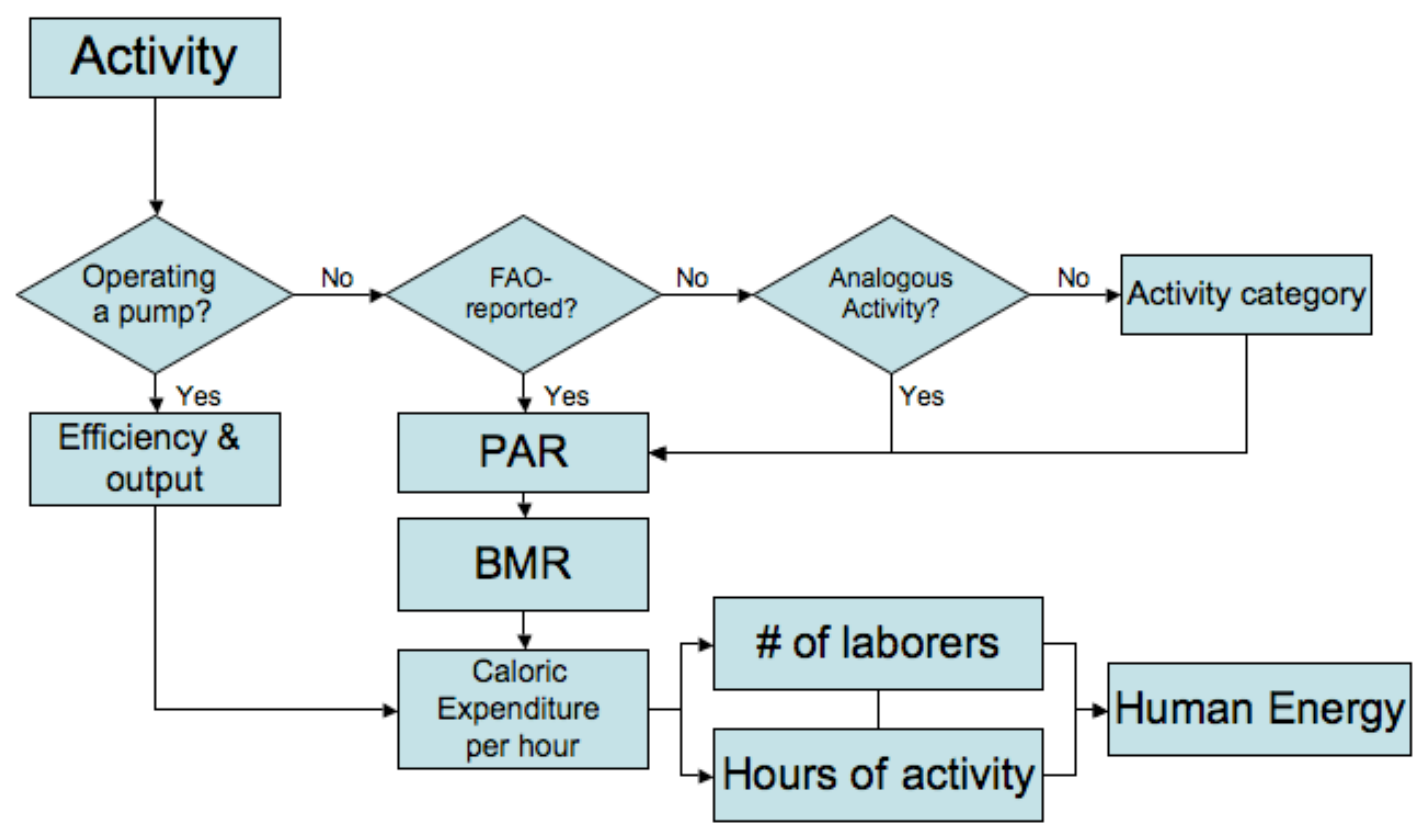

Figure 4: Flowchart summarizing human energy calculations used in this study

\subsection{Human energy expended collecting water}

The PAR for the activity of "collecting water" reported by the FAO can be interpreted in a number of ways. The text specifies that a woman collects the water from a well, but there are a wide range of collection tools and techniques that could affect the PAR for collecting water. For the purposes of this study, it is assumed that these tools and techniques are consistent with those used in Mali to collect water from a traditional well or an improved well.

Traditional gender roles dictate that women are the household members responsible for collecting water. Women have different body masses and predictive equations, but this study aims to quantify all labor equally when comparing human and material energy, and therefore a $70 \mathrm{~kg} 18-30$ year old male is used as the standard laborer. One 
might correctly expect that a $50 \mathrm{~kg} 18-30$ year old female will have a lower BMR $(5.994 \mathrm{MJ} / \mathrm{d})$ than a $70 \mathrm{~kg} 18-30$ year old male $(7.306 \mathrm{MJ} / \mathrm{d})$, women in Mali are very often pregnant or breastfeeding, which can increase daily energy demands by 2.57 3.14 MJ/d (FAO, 2001). Using a male for this case study is thus most likely an underestimate of the true energy cost of collecting and transporting water.

The PAR method cannot differentiate between the human energy needed to operate a rope pump and that needed to operate an India Mark II pump. In these cases, the pump input power and flow rate are used to determine the energy expended during operation. The energy required to operate a pump is calculated as:

$$
\text { Energy Required to Operate Pump }=\frac{(\text { Volume Pumped }) \times(\text { Input Power })}{(\text { Flowrate })}
$$

The energy required to transport the water from the pump was calculated by assuming an average distance from household to source of 75 meters (Nyong and Kanaroglou, 2001), an assumed average volume of 30 liters collected per trip, and average walking speed of 2 miles per hour. These last two assumptions are based on the author's experience. The PAR used for this activity is 3.9, equal to that reported by the FAO for walking with a $25-30 \mathrm{~kg}$ load. 


\subsection{The interventions}

Eight interventions were selected for the study, four point of use (POU) water treatment interventions and four water source protection interventions. The specific interventions were selected with the aim of covering a wide range of material and labor inputs. Table 2 lists the interventions according to the expected intensity of labor and material inputs, with POU interventions marked with an asterisk $(*)$. Descriptions of most of the interventions are provided in Mihelcic et al. (2009).

Table 2: Eight interventions evaluated in this study according to level of labor and material installation inputs. Household POU treatment interventions are marked with an asterisk $(*)$.

\begin{tabular}{|c|c|c|c|}
\hline & $\begin{array}{c}\text { Low material } \\
\text { inputs }\end{array}$ & $\begin{array}{c}\text { Medium material } \\
\text { inputs }\end{array}$ & $\begin{array}{c}\text { High material } \\
\text { inputs }\end{array}$ \\
\hline Low labor & Bleach $^{*}$ & Ceramic Filter $^{*}$ & Solar Pump \\
\hline Medium labor & Biosand Filter $^{*}$ & Boiling $^{*}$ & India Mark II \\
\hline High labor & Improved Well & Rope Pump & \\
\hline
\end{tabular}

\subsubsection{Source protection interventions}

Advantages of source improvements over household water treatments (HWTs) typically include improvements in water quantity, the need to train fewer people on the use and maintenance of the intervention, and economies of scale. Disadvantages include the need to pool maintenance and repair funds at a community level and the potential for recontamination between collection and use. Each of these interventions meets the output criterion of 8 cubic meters per day. To calculate the human energy 
and embodied energy for a village with a population of 600 and still remain in compliance with the DNH's criterion that a source not serve more than 400 people, the results calculated for a single instance of an intervention were multiplied by a factor of 1.5 .

Intervention 1: The Improved Well. The simplest among the source protection interventions studied, this intervention is commonly implemented when a traditional well is in danger of collapsing due to excessive soil erosion under the platform of the well. The traditional $\log$ and earth platform is removed, and the diameter of the mouth of the well is widened to approximately 2 meters to a depth of 2.5 meters. A reinforced concrete foundation is poured, over which concrete blocks are laid extending up to 0.5 meters above ground surface. A reinforced concrete slab with a painted metal hatch is placed over the mouth of the well. The remaining space is backfilled, a concrete apron is poured and the surface is plastered with mortar.

In calculating the human energy expended during the installation and use of an improved well, it was assumed that the users performed all labor during construction as well as during water collection. The PARs of many of the activities were calculated by assigning the activities to a PAR category. Most activities were assigned to Category II, being more strenuous than sitting quietly or walking slowly but less strenuous than chopping wood or planting corn. The exceptions were compacting the ground for the apron, pouring the concrete apron and laying bricks. 
The first activity is quite strenuous when done manually, and the last two involve lowering bricks and buckets of concrete and mortar into the well.

In estimating the human energy expended during use, the volumetric output of collection using a rope and bucket from a well $20 \mathrm{~m}$ deep was estimated to be 7.5 liters per minute, based on the observations and experience of the author.

Intervention 2: The Rope pump. Figure 5 shows a photograph of the rope pump apparatus analyzed in this study. As the user turns the crank arm, water is drawn into the rising main by a series of plungers that are attached to a continuous loop of rope. The rope is drawn over the top of the pulley wheel and lowered back into the well. A rope pump intervention as defined by this study consists of the pump apparatus installed as part of a well improvement project. That is, the bill of materials and labor includes all materials and labor required by the improved well in addition to those required for the pump apparatus. 


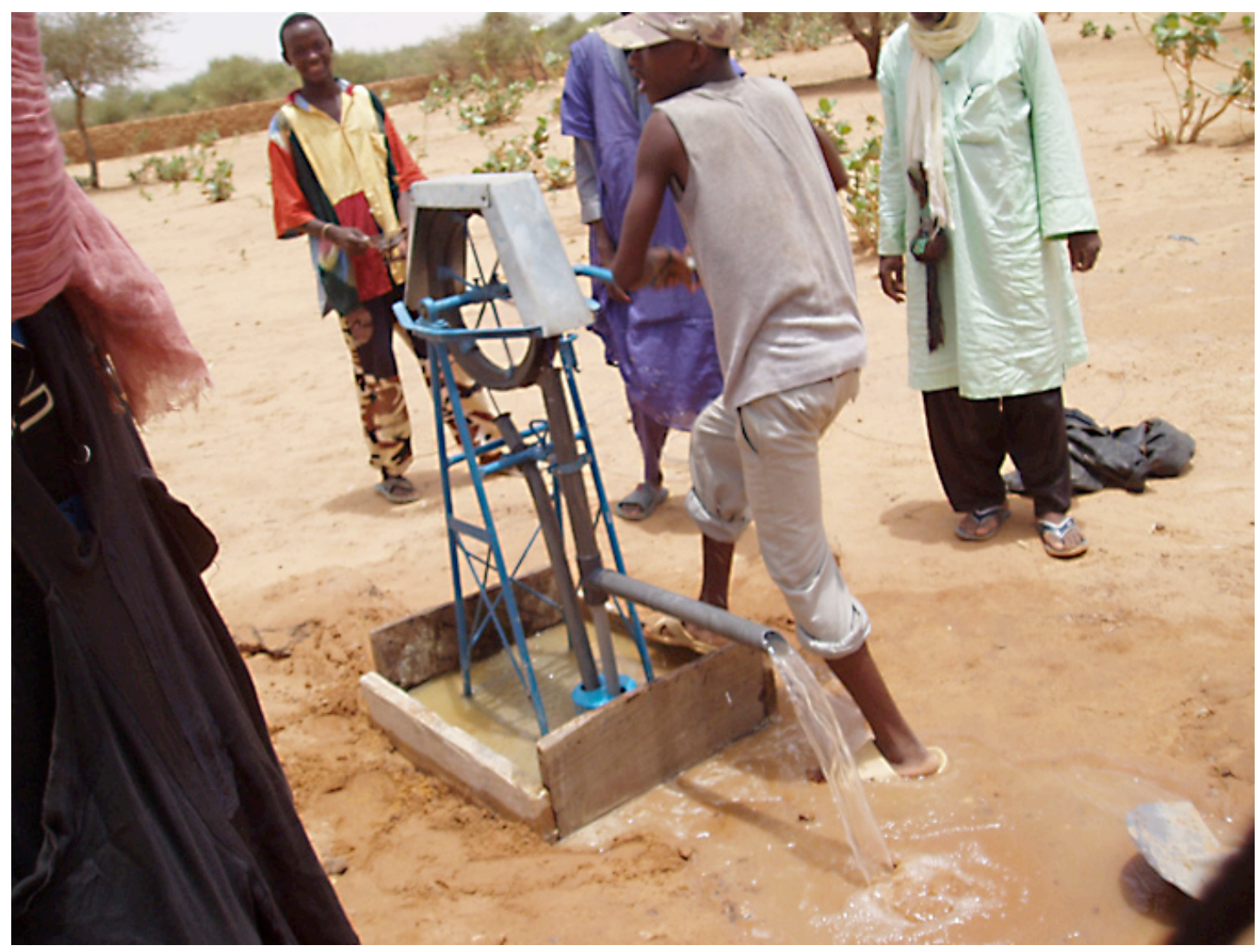

Figure 5: Photo of a rope pump installation, apron not shown (image courtesy of Michael MacCarthy)

In this case, an NGO or contractor typically assembles and installs the mechanical components of the pump. The embodied energy required for assembling and installing the pump is accounted for by a labor fee. The users construct the improved well, so the associated human energy is included.

The human energy for the use of the rope pump is calculated using estimates of 600 $\mathrm{W}$ input power and volumetric output of 20 liters per minute taken from Fraenkel, 1986. 
Intervention 3: The India Mark II hand pump. The India Mark II hand pump, shown in Figure 6, is widely used throughout Mali. It is a borehole piston pump designed to be durable and easily maintained, though it is not considered to be a village level operated and maintained (VLOM) pump. (Rural Water Supply Network, 2010) The specifications used for this study were taken from a project implemented by a Peace Corps volunteer in Kadiaradougou, Mali (Traore, 2009). In this case, as is typical in Mali, the borehole is drilled by a truck-mounted drill rig operated by Société d'Équipement et de Travaux (SETRA). The borehole depth in this case is 80 meters, with a depth to water of 20 meters and a rising main 30 meters long.

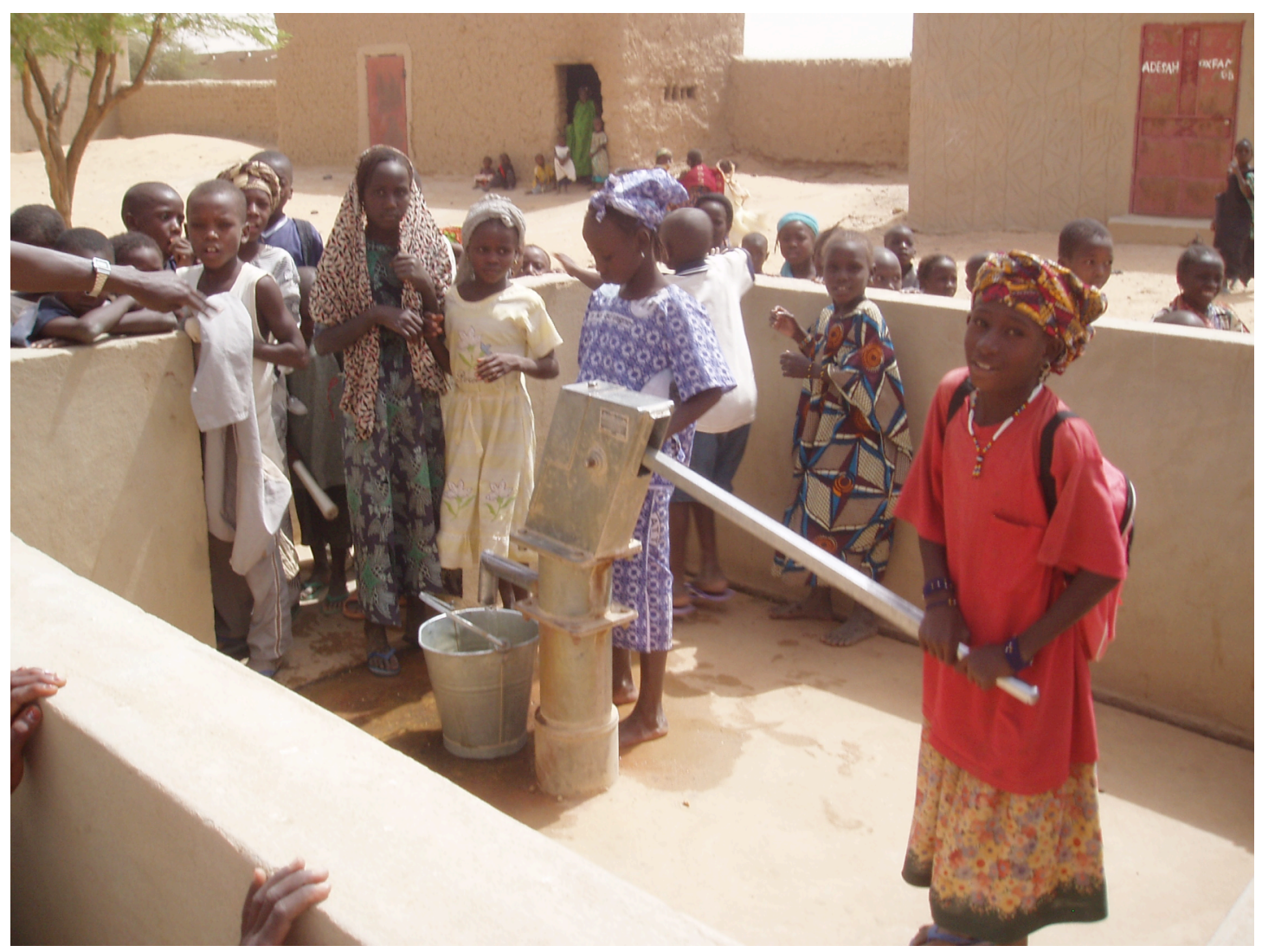

Figure 6: Photograph of the India Mark II hand pump (image courtesy of Michael MacCarthy) 
As recently as the early 2000's, there were manufacturers producing India Mark II pumps in Mali, but a reputation for poor workmanship has led to a widespread preference for the units manufactured in India (MacCarthy, 2010). For the purposes of this study, we use the input/output model of another transition economy, China, to calculate the embodied energy of the pump head.

The human energy needed for the installation of this intervention comes exclusively from the collection and sifting of the sand and gravel used to make the apron and wall. The rest of the installation labor is typically performed by SETRA. An input power of $75 \mathrm{~W}$ and a volumetric output of 1 cubic meter per hour at $20 \mathrm{~m}$ of head were used to calculate the energy required for water collection (Bauman, 2000).

Intervention 4: The Solar Pump. The most expensive of the source protection interventions, the solar pump design used for this study is based on an irrigation system promoted in northern Benin by the non-governmental organization, Solar Electric Light Fund (SELF) as described in Burney et al. 2010. The system consists of a submersible centrifugal pump optimized for intermittent operation, solar panels, piping, and a storage tank. No batteries are used in the design. The irrigation lines and pipes are part of the original design but were not included in this study. The system is installed in a borehole identical to the one described under the description of the India Mark II pump. Adjustments were made to account for the different storage requirements of irrigation and drinking water supplies. As each pump serves 400 people consuming 20 liters a day, the storage capacity of the tank was 
conservatively estimated to be 8 cubic meters. The design of a ferrocement tank of this size is adopted from a 10 cubic meter tank described by Watt (1978).

\subsubsection{Point of use interventions}

Advantages of POU interventions over source protection typically include less risk of post-collection contamination and empowering individual households to manage their own water quality needs. For these interventions, the number of households in a village of 600 people is calculated to be 52.4, based on an average household size of 11.44 people reported by (UN-HABITAT, 2010). The embodied energy and human energy needed to serve a single household was multiplied by 52.4 in order to calculate the energy requirements to serve a village. The water supplied to each household was assumed to be collected from an unimproved well.

Intervention 5: Boiling with Firewood. In this POU intervention, firewood is collected and combusted in a traditional stove to heat the water to $373 \mathrm{~K}$. As firewood is often a non-market good, the embodied energy of this intervention was not calculated using I/O analysis, but by using the method used by Clasen et al. (2008). The heat energy required to raise the temperature of a volume of water is given by $V \rho C_{p} \Delta T$, where $V$ is the volume of the water (cubic meters), $\rho$ is the density of the water $(\mathrm{kg} / \mathrm{cubic}$ meters), $C_{p}$ is the specific heat capacity of water $(4.187 \mathrm{~kJ} / \mathrm{kg} / \mathrm{K})$ and $\Delta T$ is the difference between the final and initial temperatures of the water - in this case, an assumed $75{ }^{\circ} \mathrm{C}$. The heat transfer efficiency of $8 \%$ (Eff in the equation below) used 
by Clasen et al. was assumed to include the effects of batch size and the heating of the cooking implements.

$$
\begin{aligned}
& \text { Wood energy }= \\
& (\text { volume of water }) \times(\text { density of water }) \\
& \times(\text { specific heat capacity of water }) \times(\text { increase in temperature }) \times\left(\frac{1}{E f f}\right)
\end{aligned}
$$

For the human energy calculations, the mass of the firewood collected was calculated by using an average of the calorific contents of five Sahelian trees used for firewood as reported by Lamers et al. (1994). These values are based on the dry mass of the wood, and it is common for Malians to collect and consume green wood (Benjaminsen, 1997), which has a higher density and a lower specific calorific content. This study made the simplifying assumption that wood was collected and consumed in a dry state. The number of collection trips was calculated using an average of $42.8 \mathrm{~kg}$ of wood collected per trip, as reported by Clasen et al. (2008). Round-trip collection time in the author's village was approximately 2 hours, with up to an hour spent walking between the village and the collection site, the remaining time split between chopping and collecting wood.

Intervention 6: Disinfection with Chlorine Bleach. In many village stores, domestically manufactured 12 percent chlorine bleach is sold in $250-\mathrm{ml}$ bottles. This product is promoted as a method of disinfecting drinking water by adding 2 drops of bleach per liter of water. The quantity of bleach increases with turbidity, but for the 
purposes of this study it was assumed that the source produces relatively clear water. Based on the Peace Corps' estimate of 20 drops constitutes a milliliter (Peace Corps Mali, 2006), each 250-ml bottle of bleach can treat 2,500 liters of water. An average household of 11.44 people will purchase a bottle every 10.91 days, or 335 times in ten years. The embodied energy of the bleach is calculated using the Malian Leontief inverse matrix by assigning the bleach to the other manufactured goods sector.

Intervention 7: Biosand Filter. A biosand filter (BSF) is designed to treat water for household consumption using slow sand filtration and biological activity. A typical BSF design is shown in Figure 7 and consists of an open-top concrete container filled with graded filter media, typically sand and gravel. There is an outlet pipe designed to maintain a constant and optimal level of water above the filter bed, which allows for intermittent use. A biologically active layer, or schumutzdecke, develops at the top of the filter that increases the pathogen removal efficiency of the filter (Haarhoff and Cleasby, 1991). 


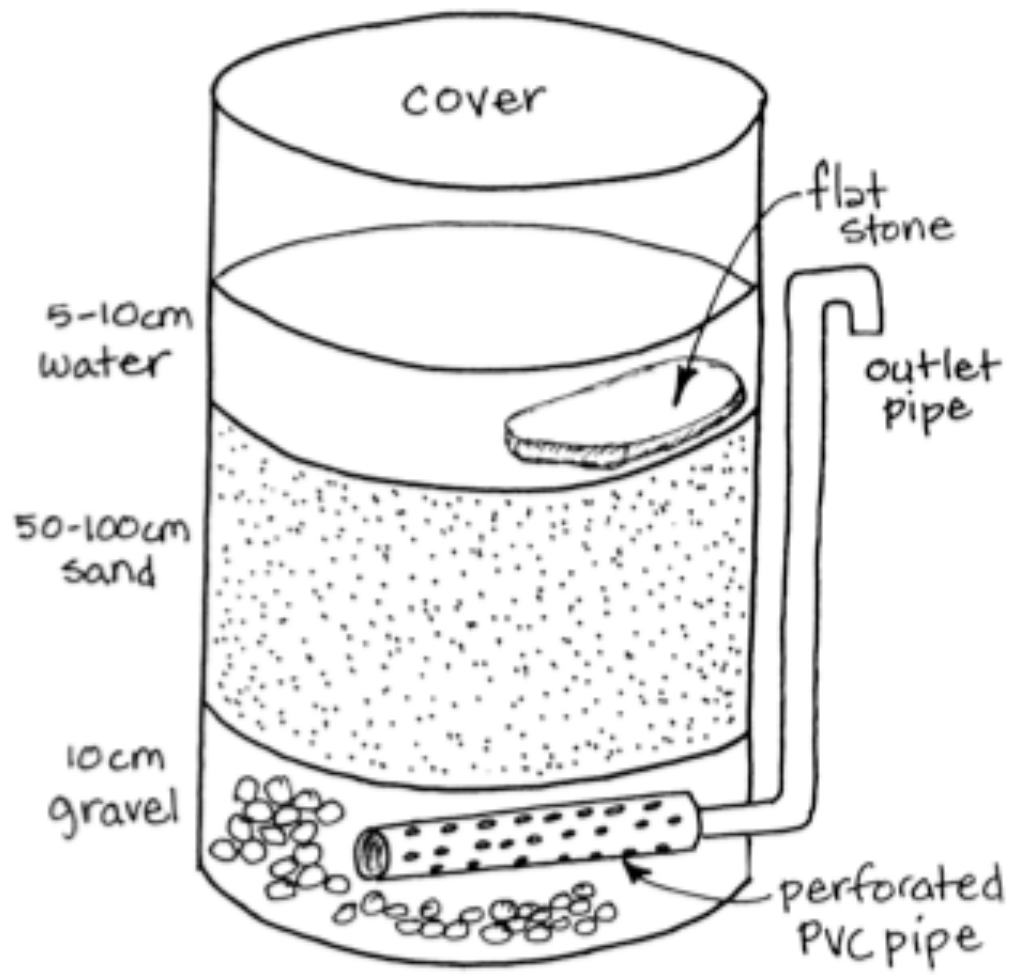

Figure 7: Sketch of a typical biosand filter (image courtesy of Linda Phillips)

The construction of the filter requires the use of specially made filter molds, which were assumed to be a sunk cost and were not included in the energy calculations. Furthermore, the actual construction of the filter is typically carried out by paid technicians rather than the user, so human energy costs of the construction were also excluded.

Intervention 8: Potters for Peace Ceramic Filter. This is a ceramic filter promoted by the non-profit organization Potters for Peace (http://www.pottersforpeace.org). A schematic of the filtration system is shown in Figure 8. Only the ceramic element was 
included in the material energy analysis. The plastic bucket and spigot shown were considered to be components of household storage, which were not included in the material costs of any of the other treatment systems, and so they were excluded from the analysis. Locally trained potters construct and market the filters.
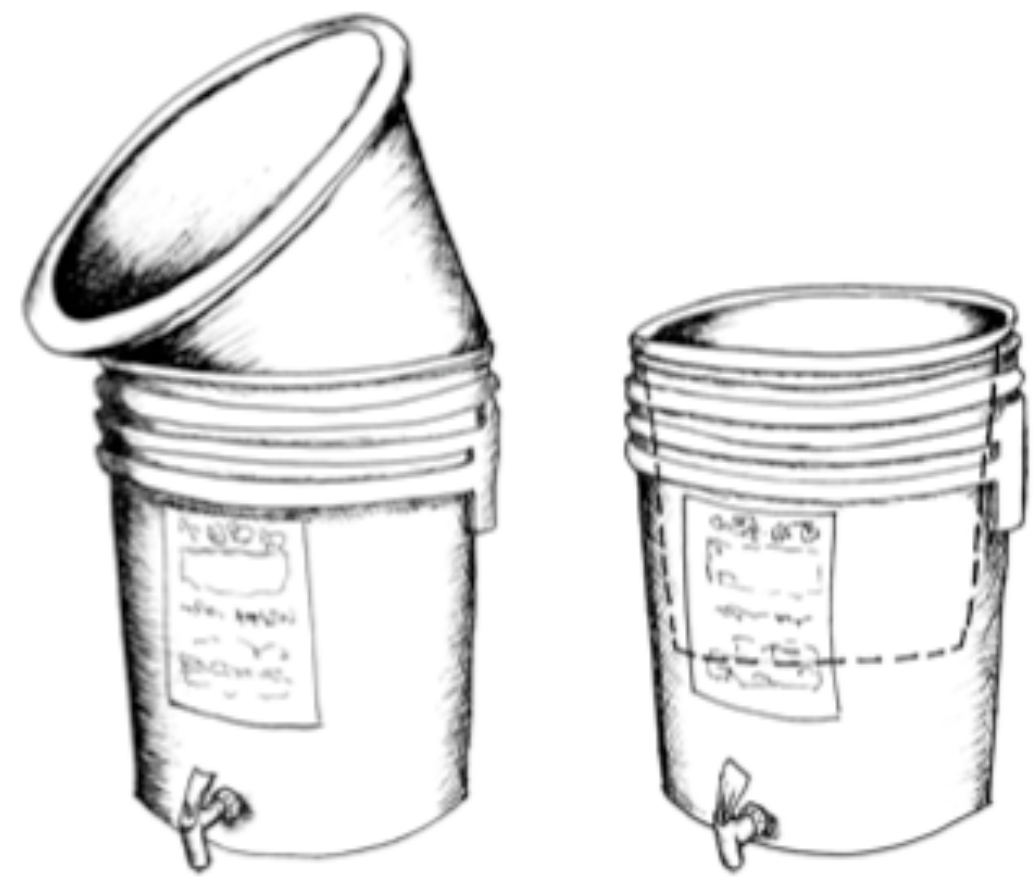

Figure 8: A sketch of the type of ceramic filter promoted by Potters for Peace (image courtesy of Linda Phillips)

The organization suggests treating the filters with colloidal silver, which acts as a microbial disinfectant (Oyanedel-Craver and Smith, 2008). This practice is highly informal, and limited to regions in Central and South America, and was not included in this analysis. Users do not typically collect and sift the clay, so this step was excluded from human energy calculations. The time spent performing this task could not be ascertained from the available information, and so the upstream human energy was not included in the material embodied energy. The embodied energy for firing 
the filter kiln was calculated using information obtained from the organization regarding the typical practices of a single kiln filter production facility (Wagoner, 2010). The energy required to fire the kiln was calculated as:

\author{
Kiln Energy $=($ volume of wood consumed per run $) \times$ \\ (density of wood $) \times($ calorific content of wood $)$
}

The density and calorific content the wood were taken from average values of five Sahelian species of tree reported by Lamers et al. (1994).

\title{
5 RESULTS AND DISCUSSION
}

Table 3 shows the total embodied energy required for a ten-year implementation of each of the selected interventions. The most striking result is that boiling with firewood requires 172,559 GJ of energy over a ten-year period, more than two orders of magnitude more energy than the next most energy intensive intervention. Because the relative difference between boiling with firewood and the remaining seven interventions is so great, boiling is omitted from several figures in this analysis for the sake of clarity and ease of comparison. Of the remaining seven interventions, the ceramic filter is the most energy intensive, requiring $343 \mathrm{GJ}$, and the rope pump is the least intensive with $117 \mathrm{GJ}$. 


\subsection{Embodied energy of point of use water treatment vs. water source protection}

One of the objectives of this study is to determine if there is a relationship between the scale of the intervention - that is, household water treatment or water source protection - and the embodied energy of the intervention. The results show that neither type of intervention is absolutely more energy intensive than the other, as some POU interventions have greater embodied energy than some source interventions and vice versa. But when the interventions of each type are ranked according to embodied energy, as in Table 3, the POU intervention at each rank is more energy intensive than the source intervention at that rank. Also shown in Table 3 , when boiling is excluded from the analysis, the standard deviation of each group $120 \mathrm{GJ}$ for POU interventions and $82 \mathrm{GJ}$ for source interventions - is greater than the difference between the means of each group, 26 GJ. Any relationship between the scale of an intervention and its embodied energy is not a strong one.

Table 3: Total embodied energy of eight interventions over a ten-year time frame

\begin{tabular}{|c|c|c|c|c|}
\hline \multicolumn{2}{|c|}{ Source Protection } & \multirow[b]{2}{*}{ Rank } & \multicolumn{2}{|c|}{ Point of Use Treatment } \\
\hline Intervention & Energy (GJ) & & Energy (GJ) & Intervention \\
\hline Solar Pump & 302 & 1 & 172,559 & Boiling \\
\hline India Mark II & 245 & 2 & 343 & Ceramic Filter \\
\hline Improved Well & 134 & 3 & 139 & Biosand Filter \\
\hline Rope Pump & 117 & 4 & 131 & Chlorination \\
\hline & $\begin{array}{r}216 \\
82\end{array}$ & $\begin{array}{c}\text { mean }^{\ddagger} \\
\text { std. dev. }\end{array}$ & $\begin{array}{l}242 \\
120\end{array}$ & \\
\hline
\end{tabular}

The other primary objective of this study is to determine the significance of the human energy component of embodied energy, particularly within the context of a subsistence farming community. Figure 9 shows the human, material, and 
transportation components of the embodied energy of each of the seven non-boiling interventions. At the outset of this study, it was expected that human energy would be small compared to the material energy of the interventions. It is surprising then, that human energy accounts for up to $97 \%$ of the total embodied energy of some interventions, as shown in Figure 10.

It was also expected that human energy would be large relative to the daily energy budget of subsistence farmers. The findings of the study showed that the daily energy cost of collecting and transporting water never exceeds $4.2 \%$ of the daily energy budget. This agrees with the FAO estimate for an individual with a vigorously active lifestyle, for whom $8 \%$ of daily energy costs are spent collecting water and firewood (FAO, 2001). For reference, an estimated four percent of electricity generation in the United States is used for water supply and treatment (Merson, 2006). 
Total Embodled Energy of Selected Interventions

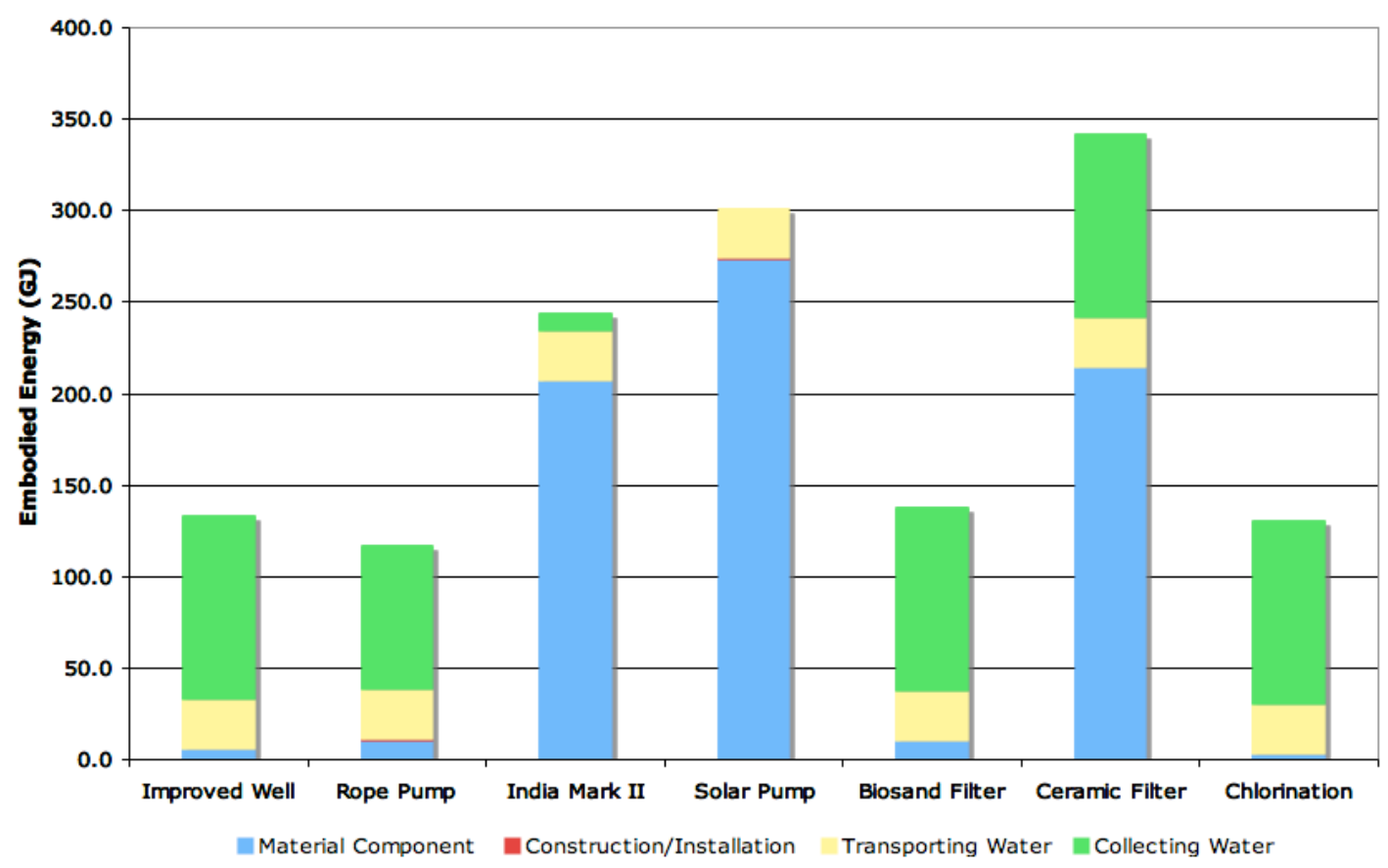

Figure 9: Total embodied energy of selected interventions

Percentage of Total Embodied Energy Expended by Humans

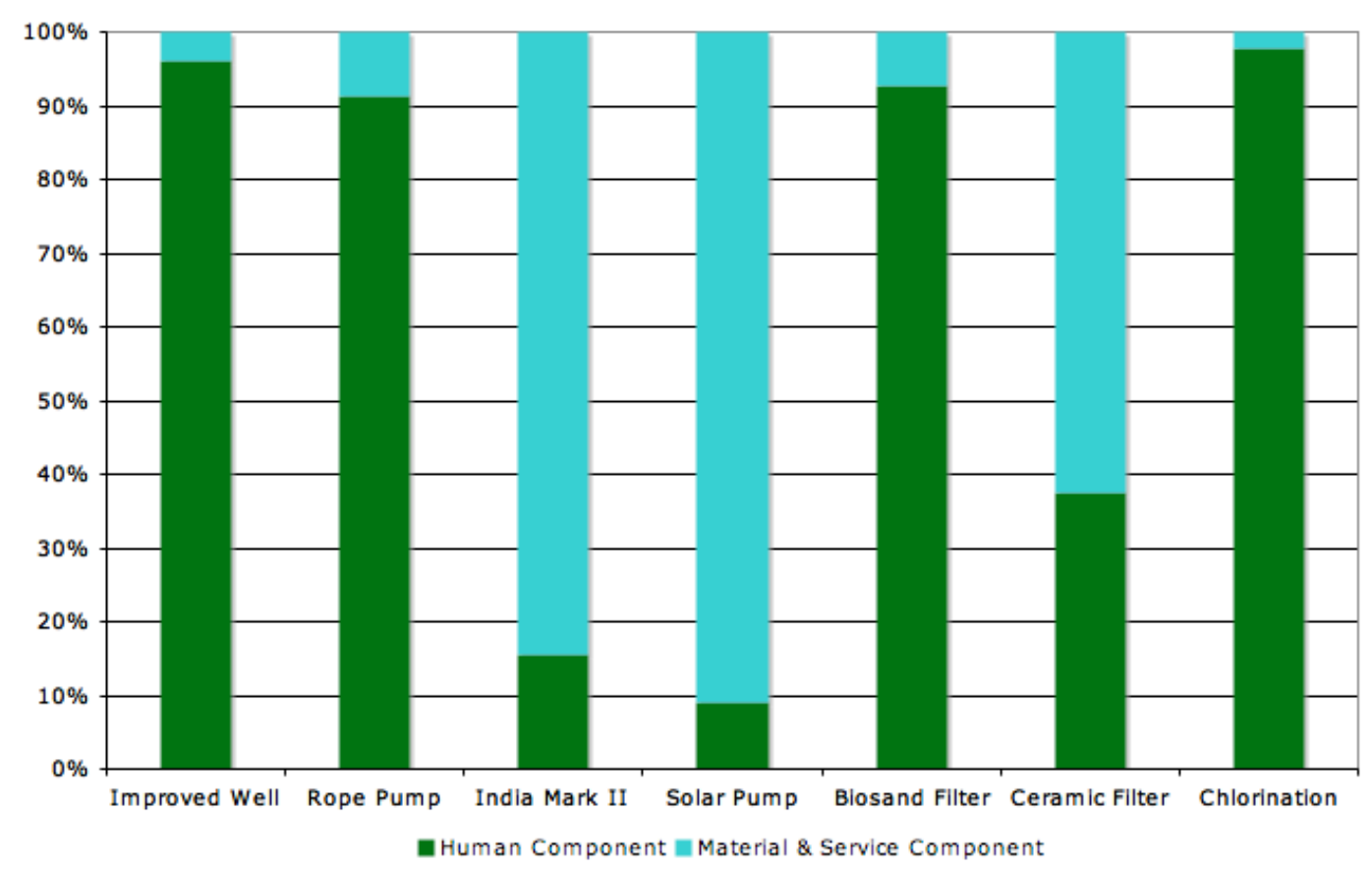

Figure 10: Percentage of Total Embodied Energy Expended by Humans 
Most of the human energy component of every intervention is attributable to collecting and transporting the water. For each POU intervention, as well as the improved well, this energy accounts for 166 GJ over ten years. This value is identical across each of these four interventions because the methods for collecting and transporting the water for traditional wells, which are used for all POU interventions, are the same as that for an improved well. The effect of pump installations is seen in the marked decrease in human energy of the three pump-based interventions. The solar pump and the India Mark II pump use significantly less energy to operate than a rope and a bucket, while the rope pump offers a smaller advantage.

Referring to Table 2 in Section 4.7, the material component of the embodied energies of the seven non-boiling interventions are roughly what was expected, with the solar pump and India Mark II being relatively energy intensive and the improved well and POU treatments being relatively energy efficient. Boiling with firewood and ceramic filters both required higher human and material inputs than expected.

\subsection{Human energy as a social sustainability indicator}

Human energy was included in this study as a potential indicator for social sustainability of water quality interventions. As described in the introduction and literature review, many development organizations structure their projects so that communities must cover a minimum portion the total project cost, often through in- 
kind contributions such as labor. The United States Peace Corps, for example, requires a minimum community contribution of $25-33 \%$ of the total project cost. Many organizations, including the Peace Corps, allow the inclusion of labor required to install an intervention, but limit or prohibit the inclusion of labor required to operate or maintain an intervention. For example, in an improved well project, the labor needed to haul the sand and widen the well would be included, but the labor required to collect water would not. Ostensibly, this is to ensure that the community has the means and motivation to continue the project beyond installation. This study shows that the labor costs of operating an intervention are much larger than that of the initial installation. Furthermore, in Mali, women are traditionally responsible for the collection of water, whereas men are traditionally responsible for most of the work involved in installing the interventions (e.g., hauling sand). Table 4 lists the percentage of total human energy by gender for each intervention. With the exception of boiling water, where it was assumed that men perform an equal share of the chopping and collecting of firewood, the women's share of the work exceeds $99 \%$. Human energy, in the context of water quality interventions, is thus related to gender equality.

Table 4: Percentage of human energy performed by women

\begin{tabular}{rc}
\hline Intervention & Human Energy Expended by Women (\%) \\
\hline Improved Well & 99.73 \\
Rope Pump & 99.62 \\
India Mark II & 99.88 \\
Solar Pump & 99.45 \\
Biosand Filter & 99.98 \\
Ceramic Filter & 100.00 \\
Chlorination & 100.00 \\
Boiling & 62.18 \\
\hline
\end{tabular}




\subsection{Balancing human and material energy}

As one might expect, there is a tradeoff between human and material energy between the source interventions. For example, the solar pump has a higher material energy than the India Mark II hand pump, but it offers significant human energy savings. The same is true of the India Mark II and the improved well. A notable exception is the rope pump, which has higher material energy than the improved well, but the savings in human energy actually causes a net reduction in embodied energy.

One might suggest that a gigajoule is a gigajoule and that the reduced human energy burdens offered by interventions like a solar pump are offset by the increased material energy. But as noted in the literature review, human energy and utility-supplied electricity have very different costs. If this cost difference is used to assign to value each type of energy, the results are quite surprising. For example, the solar pump requires an additional $268 \mathrm{GJ}$ of material energy, but saves $130 \mathrm{GJ}$ in human energy relative to an improved well. For the purposes of illustration, the price of material energy is assumed to be $\$ 0.1 / \mathrm{kWh}$ and the price of human energy is assumed to be $\$ 3.54 / \mathrm{kWh}$, as in the literature review. Under this valuation, the net savings of installing a solar pump instead of a traditional well are in excess of $\$ 120,000$ over ten years. That is over six times the initial cost of installing the intervention. Table 5 shows the evaluated energy savings and the cost of the three water source protection interventions relative to an improved well. It appears that under this valuation, the additional cost of reducing human energy burdens is well justified. 
Table 5: Evaluated energy savings of source protection interventions

\begin{tabular}{rccc}
\hline & \multicolumn{3}{c}{ Source Protection Intervention } \\
\cline { 2 - 4 } Evape Pump & India Mark II & Solar Pump \\
& 49,588 & 111,963 & 120,078 \\
Cost of materials (\$) & 430 & 11,638 & 18,212 \\
\hline
\end{tabular}

\subsection{Qualifying assumptions and simplifications}

This study made a number of assumptions and simplifications that introduced a degree of uncertainty to the data. To the author's knowledge, there are no known ways to quantify this uncertainty, so an effort is made here to qualify the effects of these assumptions.

One of the major assumptions regarding the calculation of embodied energy using I/O analysis is the use of I/O matrices from different countries. To the author's knowledge, this is the first study to use this approach to calculating embodied energy in a global economy. The selection of an I/O model can have a large effect on the embodied energy of a material. For example, Table 6 shows the embodied energy required to produce a metric ton of cement as calculated using the $\mathrm{I} / \mathrm{O}$ models of Mali, the United States, Canada and China. The process-based value used in this study is also included.

Table 6: Embodied energy of 1 tonne of cement by source and model

\begin{tabular}{r|l}
\hline Source [model] & Embodied energy (MJ) \\
\hline Mali $[\mathrm{I} / \mathrm{O}]$ & 142 \\
United States [I/O] & 23,800 \\
Canada $[\mathrm{I} / \mathrm{O}]$ & 709 \\
China $[\mathrm{I} / \mathrm{O}]$ & 18,100 \\
Literature [process data] & 4,750 \\
\hline
\end{tabular}


Even between two countries of similar wealth and geography, such as Canada and the United States, the variation in embodied energy can be extremely large. In this case, using the Malian I/O matrix rather than process data would lower the material component of embodied energy. If a different I/O model (e.g., China's) were to be used, the material component of embodied energy of most interventions would increase substantially.

For the reasons outlined in the methods section, this study used China and the United States as the supplier countries for the two material types most frequently used in the interventions: steel and PVC plastic. The United States and China also appear to have the most energy intensive I/O models, so substitution of other I/O models can be expected to lower the material component of the embodied energy of most interventions, perhaps by an order of magnitude or more.

It is also likely that the highly aggregated nature of the Malian $\mathrm{I} / \mathrm{O}$ matrix causes considerable uncertainty in the embodied energy estimates of borehole drilling and bleach. Without more data to validate the matrix, it is impossible to be sure how this affects the results. However, it is the author's opinion that the data in the existing matrix is of good quality, as it has been used in other studies to derive social accounting matrices and computable general equilibrium models (Estache et al., 2007; Savard, 2010). 
The method by which water and energy were disaggregated is mathematically sound but uses data from disparate sources. It is possible that differences in data collection techniques between the sources could introduce uncertainty into the model. Calculations found that $95 \%$ of the output of the electricity, energy and water sector is related to electricity and energy. This suggests that, the calculations most likely overestimated the embodied energy of borehole drilling services and household bleach.

Two major simplifications were the omission of energy costs associated with overland transportation and maintenance. The energy cost of overland transportation was assumed to be small compared to overseas transportation. Overseas transportation was calculated to be less than $1 \mathrm{GJ}$ for each intervention. This is very small compared to the total embodied energy of each intervention. The omission of overland transportation energy thus appears to be appropriate.

The execution of proper maintenance is a major challenge for many users of these interventions. For example, DNH (2004) estimated that nearly a third of the hand pumps in Mali are non-operational, and suggested that a lack of leadership and organization of users is partly to blame. However, the typical maintenance points of these hand pumps are generally inexpensive (SETRA, 2009) and infrequent (Shaw, 1999) and therefore unlikely to contribute significantly to the embodied energy. The most expensive components of the solar pump are also expected to last 10-15 years without significant maintenance or replacement (Burney et al., 2010). The most 
frequent maintenance point of the rope pump is a broken rope, which is made from locally recycled materials and replacement would not contribute to the total embodied energy. For the POU treatments, the most notable maintenance activity excluded from the study is the occasional replacement of a portion of the filter media in a sand filter. This would have a very slight net increase in the human energy component. The exclusion of maintenance activities does not appear to change the results significantly.

\section{CONCLUSIONS}

When analyzed at the village level, household-scale interventions appear to have a slightly higher total embodied energy than source-scale interventions, though there is much variation within each type. The human energy component of total embodied energy is larger than hypothesized. Most of this human energy component is generally comprised of energy required to collect and transport water, labor that is typically performed by women. Human energy in water quality interventions is thus related to gender equality and relevant as a social sustainability indicator. The material costs associated with reducing the human energy burden of collecting water appear to be justified when using an appropriate valuation for human and material energy. Overall, human energy plays an important role in the provision of clean drinking water in Mali, and deserves appropriate consideration when evaluating interventions for potential implementation at the village level. 


\section{RECOMMENDATIONS FOR FURTHER STUDY}

This study made a number of assumptions due to significant knowledge gaps. Some of the gaps are easier to fill than others, such as the flow rate achievable by drawing water with the usual tools and methods used in Mali, the average number of liters of water collected per trip, and more realistic accounting of maintenance costs. Other knowledge gaps are more challenging to fill, such as building I/O models and transformation matrices for countries where they are lacking. Filling this gap would reduce uncertainty in studies like this one, and potentially provide an opportunity to understand the large variability between models when calculating the embodied energy of common materials.

There are many ways to add depth to the analysis of the importance of human energy in water quality interventions. For example, this study did not account for a time preference for energy, a factor that could potentially be incorporated through the introduction of a social discount rate. Furthermore, as Mali continues to develop, changing demographics and economic conditions could also change the value of labor, which would affect the trade-off dynamics of material and human energy. This study only briefly touched on a simple valuation of human energy. A more nuanced approach, such as quantifying the opportunity cost of time spent collecting water, may also have merit. None of the interventions in this study included provisions for drinking water distribution. The human energy and total embodied energy of interventions of this type should be analyzed as well. There is also potential to 
develop a participatory tool for teaching communities about energy costs and their impacts on gender equality.

Human energy and total embodied energy are useful new prisms through which to view one of the oldest and most discussed issues in development. The author offers the results of this study to community leaders and development practitioners as another factor to consider when assessing the potential impacts of their water quality interventions.

\section{WORKS CITED}

Basu S.R., H.A.C Main. (2001). "Calcutta's water supply: demand, governance and environmental change." Applied Geography. 21 (1): 23-44.

Baumann E. Water Lifting. Series of Manuals on Drinking Water Supply. 7. Switzerland: SKAT, St. Gallen; 2000.

Benjaminsen, T. (1997). "Is there a firewood crisis in rural Mali?" GeoJournal 43(2): 163-174.

Boesch, M.E., and S. Hellweg (2010). "Identifying Improvement Potentials in Cement Production with Life Cycle Assessment." Environmental Science \& Technology. 44 (23): 9143-9149.

Boisson, S., W. Schmidt, T. Berhanu, H. Gezahegn, T. Clasen. (2009). "Randomized controlled trial in rural Ethiopia to assess a portable water treatment device." Environmetnal Science \& Technology. 43(15): 5934-5939.

Boisson, S. M. Kiyombo, L. Sthreshley, S. Tumba, J. Makambo, T. Clasen (2010). "Field Assessment of a Novel Household-Based Water Filtration Device: A Randomised, Placebo-Controlled Trial in the Democratic Republic of Congo." PloS one. 5 (9)

Burney, J., L. Woltering, M. Burke, R. Naylor, D. Pasternak. (2010). "Solar-powered drip irrigation enhances food security in the Sudano-Sahel." Proceedings of the National Academy of Sciences 107(5): 1848-1853. 
Campbell, E. "Study on Life Span of Ceramic Filter Colloidal Silver Pot Shaped (CPS) Model.” Potters for Peace. Managua, Nicaragua. (2005).

Carbonfund.org (2010). How We Calculate Your Carbon Footprint. [Internet], available from http://www.carbonfund.org accessed November 1, 2010.

Carnegie Mellon University Green Design Institute. (2010) General Information about EIO-LCA. [Internet], available from http://www.eiolca.net Accessed November $1,2010$.

Carnegie Mellon University Green Design Institute. (2008a) Economic Input-Output Life Cycle Assessment (EIO-LCA) Industry Benchmark Canada EIO model from 2002 [Internet], available from http://www.eiolca.net Accessed November 1, 2010.

Carnegie Mellon University Green Design Institute. (2008b) Economic Input-Output Life Cycle Assessment (EIO-LCA) China 2002 model [Internet], available from http://www.eiolca.net Accessed November 1, 2010.

Carnegie Mellon University Green Design Institute. (2008c) Economic Input-Output Life Cycle Assessment (EIO-LCA) Spanish 2000 EIO model [Internet], available from http://www.eiolca.net. Accessed November 1, 2010.

Carnegie Mellon University Green Design Institute. (2008d) Economic Input-Output Life Cycle Assessment (EIO-LCA) US 2002 Benchmark model [Internet], available from http://www.eiolca.net Accessed November 1, 2010.

Central Intelligence Agency, (2010). The World Factbook. Accessed November 1, 2010. http://www.cia.gov/library/publications/the-world-factbook/

Center for Sustainable Systems, University of Michigan (2009). "U.S. Energy System Factsheet" Pub. No. CSS03-11.

Clasen, T. (2008). Water Quality Interventions for the Prevention of Diarrhoeal Disease: effectiveness, cost-effectiveness and recent research." Presented at Michigan Technological University.

Clasen, T., J. Bartram, J. Colford, S. Luby, R. Quick, M. Sobsey (2009). "Comment on "Household water treatment in poor populations: Is there enough evidence for scaling up now?"." Environment Science \& Technology. 43 (14): 5542-5544.

Clasen, T. and A. Bastable (2003). "Faecal contamination of drinking water during collection and household storage: the need to extend protection to the point of use." Journal of Water and Health. 1 (3): 109-116. 
Clasen, T., D. Thao, S. Boisson, O. Shipin (2008). "Microbiological effectiveness and cost of boiling to disinfect drinking water in rural Vietnam." Environmental Science \& Technology. 42(12): 4255-4260.

Clasen, T. and S. Cairncross (2004). "Editorial: Household water management: Refining the dominant paradigm." Tropical Medicine \& International Health. 9 (2): 187-191.

Clasen, T., L. Haller, D. Walker, J. Bartram, S. Cairncross (2007). "Costeffectiveness of water quality interventions for preventing diarrhoeal disease in developing countries." Journal of water and Helth 5(4): 599-608.

Coley, D. and E. Goodliffe (1998). "The embodied energy of food: the role of diet." Energy policy. 26 (6): 455-459.

DHS (2006) Mali Demographic and Health Survey. Available on the World Wide Web at http://www.measuredhs.com/pubs/pub details.cfm?id=759 Last accessed November 1, 2010.

Direction Nationale de l'Energie (2007). Systeme d'Information Energetique du Mali: Rapport 2007. Bamako, Mali.

Direction Nationale Hydraulique du Mali (2004) Le Plan National d'Accès à l'Eau Potable. Bamako, Mali.

Esrey, S. (1996). "Water, waste, and well-being: a multicountry study." American journal of epidemiology. 143: $608-623$.

Esrey, S. and R. Feachem and J.M. Hughes. (1985). "Interventions for the control of diarrhoeal diseases among young children: improving water supplies and excreta disposal facilities." Bulletin of the World Health Organization. 63: 757-772.

Esrey, S., J. Potash, L. Roberts, C. Shiff (1991). "Effects of improved water supply and sanitation on ascariasis, diarrhoea, dracunculiasis, hookworm infection, schistosomiasis, and trachoma." Bulletin of the World Health Organization. 69: 609 621.

Estache, A., J. Perrault, L. Savard (2007). "Impact of Infrastructure Spending in Mali: A CGE modeling approach." GREDI.

Food and Agriculture Organization (2001). Human Energy Requirements: Report of a Joint FAO/WHO/UNU Expert Consultation. Food and Nutrition Technical Report Series. Volume 1. Rome. 
Fraenkel, P. (1986). Water-pumping devices: a handbook for users and choosers. Intermediate Technology Publications. United Kingdom.

GREAT Mali (2010). Available on the Internet at http://www.greatmali.net/. Accessed November, 2010.

Haarhoff, J.; Cleasby, J.L. (1991). Biological and physical mechanisms in slow sand filtration. In: Slow Sand Filtration. Logsdon, G.S. (ed.). pp. 19-68. American Society of Civil Engineers, New York, USA.

Halpem, B.S., S. Walbridge, K. A. Selkoe, C. V. Kappel, F. Micheli, C. D’Agrosa, J. F. Bruno, K. S. Casey, C. Ebert, H.E. Fox, R. Fujita, D. Heinemann, H.S. Lenihan, E. M. P. Madin, M. T. Perry, E. R. Selig, M. Spalding, R. Steneck, R. Watson (2008).

“A Global Map of Human Impact on Marine Ecosystems." Science. 319 (5865): 948952.

Hofkes, E.H., (ed.) (1987). Small community water supplies; technology of small water supply systems in developing countries. International Reference Centre for Community Water Supply and Sanitation. Wiley. New York.

Hong, L., Z. P. Dong, H. Chunyu, W. Gang. (2007). "Evaluating the effects of embodied energy in international trade on ecological footprint in China." Ecological Economics. 62 (1): 136-148.

International Trade Center (2010). Trade Competitiveness Map. [Internet]. Available from http://www.intracen.org. Accessed November 1, 2010.

Kyessi, A. (2005). "Community-based urban water management in fringe neighbourhoods: the case of Dar es Salaam, Tanzania." Habitat International 29(1): 125 .

Lamers, J. and K. Michels, R. J. Vandenbeldt (1994). "Trees and windbreaks in the Sahel: establishment, growth, nutritive, and calorific values." Agroforestry Systems

Lenzen, M. and C. Dey (2000). "Truncation error in embodied energy analyses of basic iron and steel products." Energy.

Lenzen, M. and G. Treloar (2002). "Embodied energy in buildings: wood versus concrete--reply to Börjesson and Gustavsson." Energy policy 30(3): 249-255.

MacCarthy, M. (2010). Personal Communication with Brendan Held, November, 2010. 
Merson, J.A. (2006). "Energy Demands on Water Resources Report to Congress on the Interdependency of Energy and Water." U.S. Department of Energy.

Mihelcic, J.R., E.A. Myre, L.M. Fry, L.D. Phillips, B.D. Barkdoll. (2009). Field Guide in Environmental Engineering for Development Workers: Water, Sanitation, Indoor Air, American Society of Civil Engineers (ASCE) Press, Reston, VA, 2009.

Mo, W. et al. (2010). "Measuring the Embodied Eenrgy in Drinking Water Supply Systems: A Case Study in The Great Lakes Region." Environmental Science \& Technology. DOI: 10.1021/es1015845

Nyong, A.O. and P.S. Kanaroglou (2001). "A survey of household domestic wateruse patterns in rural semi-arid Nigeria." Journal of Arid Environments. 49: 387-400.

Oyandedel-Carver, V.A., and J.A. Smith (2008). "Sustainable Colloidal-SilverImpregnated Ceramic Filter for Point-of-Use Water Treatment." Environmental Science \& Technology. 42(3):927-933.

Peace Corps Mali (2006). Cross-cultural Training Guide. Bamako, Mali.

Peter-Varbanets, M., C. Zurbrugg, C. Swartz, W. Pronk. (2009). Decentralized systems for potable water and the potential of membrane technology. Water Research 43(2): 245-265.

Potters for Peace (2010). General Brochure. Potters for Peace. Arizona.

Rural Water Supply Network. (2010). India Mark II Pump.

http://www.rwsn.ch/prarticle.2005-10-25.9856177177/prarticle.2005-10-

26.2582788867/prarticle.2008-12-04.2105225472/prarticle.2009-02-

09.3416702894/prarticle view. Last accessed November 30, 2010.

Savard, L. (2010). Personal Communication with Brendan Held, April, 2010.

Schmidt, W. and S. Cairncross (2009). "Household water treatment in poor populations: is there enough evidence for scaling up now?" Environmental Science \& Technology 43(4): 986-992.

SETRA (2009). Barême SETRA, Nomenclature et code de commande des pieces. Bamako, Mali.

Shaw, R. (ed.) (1999) Running Water: More Technical Briefs on Health, Water and Sanitation. Intermediate Technology Publications. London, UK. 1999.

Stokes, J. and A. Horvath (2006). "Life cycle energy assessment of alternative water supply systems." International Journal of Life Cycle Assessment. 11(5): 335-343. 
Suh, S. and G. Huppes (2005). "Methods for life cycle inventory of a product." Journal of Cleaner Production. 13(7): 687-697.

Sutton, S. (2010). Accelerating Self Supply: A Case Study from Mali. Field Note No 2010-1. Rural Water Supply Network. Switzerland.

Traore, B. (2009). Devis pour installation de pump a Kadiaradugu. Sikasso, Mali.

Treloar, G., P. Love, G. Holt (2001). "Using national input-output data for embodied energy analysis of individual residential buildings." Construction Management and Economics. 19(1): 49-61.

UN-HABITAT (2010). Mali In: UN-Habitat Statistics Programs Human Settlements Conditions and Trends. [Internet]. Available from http://ww2.unhabitat.org/habrdd/conditions/wafrica/Mali.htm. Last accessed November 30, 2010.

United Nations (1998). Mali. In: Ground Water in North and West Africa. Natural Resources/Water Series No. 18. New York. pp. 247-264. (1998).

United Nations. (2010). The Millennium Development Goals Report 2010. New York.

Wagoner, K. Personal communication with Brendan Held. November, 2010.

WaterAid Burkina Faso. (2009). Document Technique de la Rope Pump. WaterAid Burkina Faso. Ouagadougou, Burkina Faso.

Watt, S.B. (1978). "Ferrocement water tanks and their construction!" 118. Intermediate Technology Publications. United Kingdom.

Zérah, M. (2000). "Household strategies for coping with unreliable water supplies: the case of Delhi." Habitat International 24 (3): 295-307. 
APPENDIX A: LEONTIEF INVERSE MATRIX FOR THE MALIAN ECONOMY (GREAT, 2006)

\begin{tabular}{|c|c|c|c|c|c|c|c|c|c|c|c|c|c|c|c|c|c|}
\hline 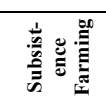 & 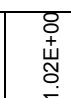 & 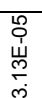 & 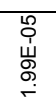 & 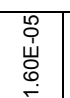 & 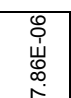 & 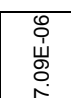 & 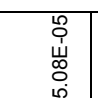 & 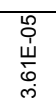 & 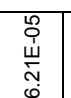 & 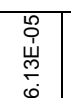 & 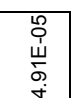 & 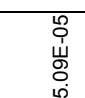 & 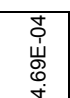 & 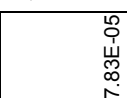 & 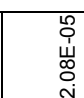 & 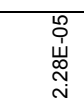 & 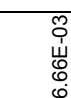 \\
\hline$\stackrel{\mathscr{\Xi}}{\approx}$ & 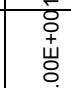 & $\begin{array}{l}\stackrel{8}{+} \\
\stackrel{+}{W}\end{array}$ & 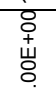 & $\begin{array}{l}8 \\
\stackrel{+}{4} \\
\stackrel{4}{0}\end{array}$ & $\begin{array}{l}8 \\
\stackrel{+}{+} \\
\stackrel{4}{\leftrightarrow}\end{array}$ & $\begin{array}{l}0 \\
\stackrel{+}{+} \\
\stackrel{4}{\leftrightarrow}\end{array}$ & $\begin{array}{l}0 \\
\stackrel{+}{山} \\
\stackrel{4}{0}\end{array}$ & 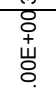 & 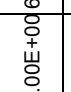 & 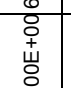 & $\begin{array}{l}\text { هे } \\
\text { वे } \\
\text { هे }\end{array}$ & 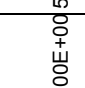 & 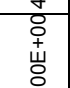 & 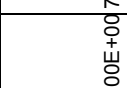 & 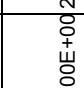 & 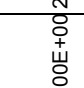 & 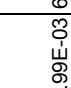 \\
\hline 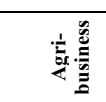 & 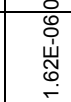 & 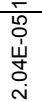 & 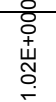 & 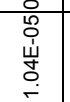 & 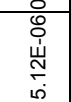 & 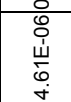 & 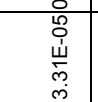 & 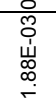 & 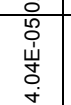 & 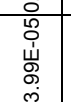 & 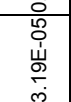 & 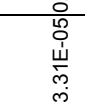 & 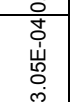 & 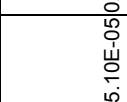 & 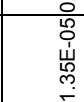 & 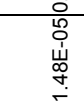 & 究 \\
\hline 言 & 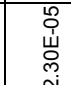 & 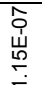 & 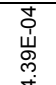 & 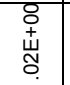 & 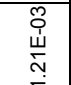 & 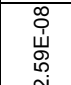 & 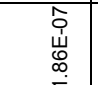 & 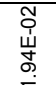 & 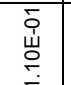 & 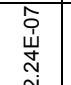 & 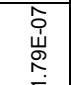 & 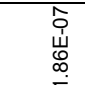 & 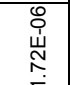 & 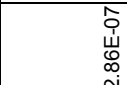 & 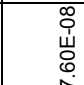 & 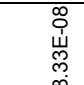 & 岁 \\
\hline 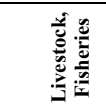 & 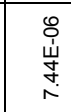 & 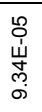 & 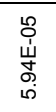 & 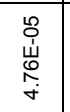 & 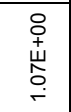 & 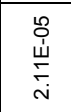 & 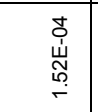 & 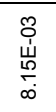 & 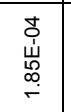 & 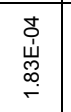 & 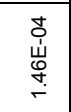 & 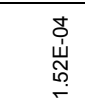 & 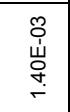 & 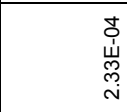 & 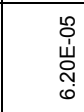 & 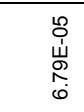 & 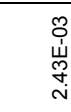 \\
\hline 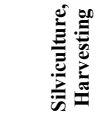 & 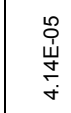 & 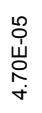 & 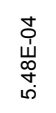 & 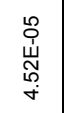 & $\begin{array}{l}\stackrel{+}{+} \\
\stackrel{\leftrightarrow}{W} \\
\stackrel{\omega}{\infty}\end{array}$ & 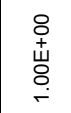 & 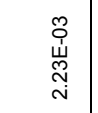 & 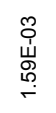 & 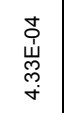 & 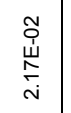 & 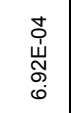 & 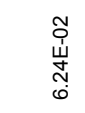 & $\begin{array}{l}\stackrel{\bullet}{0} \\
\stackrel{\leftrightarrow}{山} \\
\stackrel{\infty}{\infty} \\
\infty\end{array}$ & $\begin{array}{l}\stackrel{0}{0} \\
\text { ய̛̣ } \\
\stackrel{\leftrightarrow}{\circ}\end{array}$ & 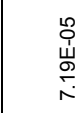 & 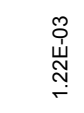 & 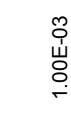 \\
\hline 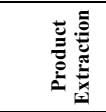 & $\begin{array}{l}0 \\
0 \\
\stackrel{u}{0} \\
0 \\
0\end{array}$ & 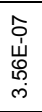 & 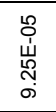 & 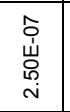 & 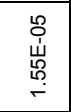 & 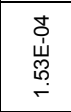 & 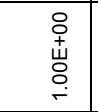 & 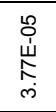 & $\begin{array}{l}\text { 足 } \\
\text { 岕 } \\
\text { N̦ }\end{array}$ & $\begin{array}{l}\stackrel{0}{0} \\
\underset{W}{W} \\
\infty \\
\infty \\
\infty\end{array}$ & 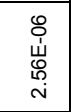 & 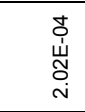 & 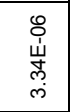 & 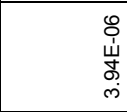 & 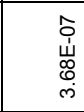 & $\begin{array}{l}\stackrel{0}{0} \\
\dot{山} \\
0 \\
\dot{\gamma}\end{array}$ & 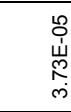 \\
\hline 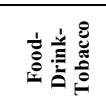 & 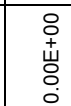 & 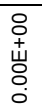 & $\begin{array}{l}\stackrel{8}{0} \\
\dot{山} \\
\stackrel{\Delta}{0} \\
0\end{array}$ & $\begin{array}{l}\stackrel{8}{0} \\
\dot{山} \\
\stackrel{\Delta}{0} \\
0\end{array}$ & $\begin{array}{l}\stackrel{0}{\circ} \\
+ \\
\stackrel{4}{0} \\
0\end{array}$ & 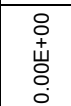 & 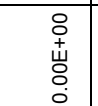 & 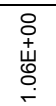 & $\begin{array}{l}\stackrel{+}{ } \\
+ \\
\stackrel{4}{0} \\
0\end{array}$ & $\begin{array}{l}\stackrel{0}{0} \\
+ \\
\dot{山} \\
0 \\
0\end{array}$ & 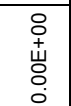 & 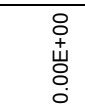 & $\begin{array}{l}\stackrel{0}{0} \\
+ \\
\stackrel{4}{0} \\
0\end{array}$ & 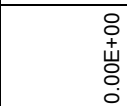 & $\begin{array}{l}\text { 우 } \\
\text { 山े } \\
\text { o } \\
0\end{array}$ & $\begin{array}{l}\text { o } \\
\text { 岀 } \\
\text { ه. }\end{array}$ & 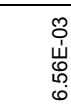 \\
\hline & 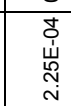 & 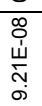 & 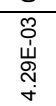 & 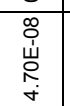 & 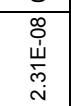 & 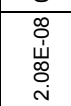 & 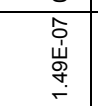 & 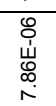 & 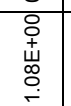 & 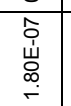 & 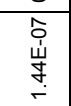 & 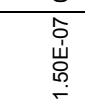 & 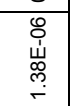 & 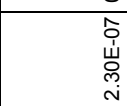 & 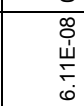 & 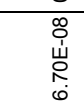 & 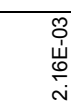 \\
\hline 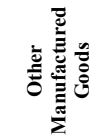 & 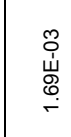 & 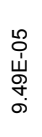 & 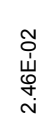 & $\begin{array}{l}\stackrel{0}{0} \\
\stackrel{\leftrightarrow}{W} \\
\hat{0} \\
0 \\
0\end{array}$ & 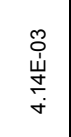 & 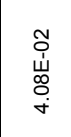 & 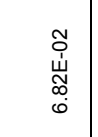 & $\begin{array}{l}\stackrel{N}{0} \\
\stackrel{\leftrightarrow}{\breve{~}} \\
\stackrel{-}{-}\end{array}$ & 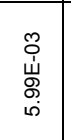 & $\begin{array}{l}\stackrel{8}{+} \\
\text { 峞 } \\
\stackrel{0}{\leftarrow}\end{array}$ & $\begin{array}{l}\stackrel{+}{0} \\
\underset{\omega}{W} \\
0 \\
0\end{array}$ & 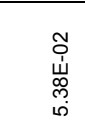 & 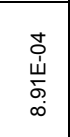 & 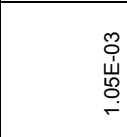 & $\begin{array}{l}\stackrel{0}{0} \\
\dot{\omega} \\
\stackrel{0}{o} \\
o\end{array}$ & $\begin{array}{l}\stackrel{0}{8} \\
\stackrel{\leftrightarrow}{\leftrightarrow} \\
\stackrel{\leftrightarrow}{+}\end{array}$ & 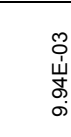 \\
\hline 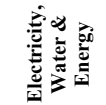 & 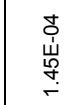 & & 总 & 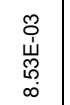 & $\begin{array}{l}\stackrel{0}{0} \\
\stackrel{\leftrightarrow}{\leftrightarrow} \\
\stackrel{\leftrightarrow}{N}\end{array}$ & $\begin{array}{l}+ \\
\stackrel{+}{0} \\
\stackrel{्}{0} \\
0 \\
\infty\end{array}$ & 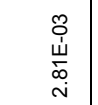 & 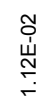 & 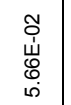 & $\begin{array}{l}\stackrel{N}{+} \\
\stackrel{\leftrightarrow}{W} \\
\stackrel{\infty}{\leftarrow}\end{array}$ & $\begin{array}{l}\stackrel{8}{+} \\
\text { 岁 } \\
\stackrel{+}{r}\end{array}$ & 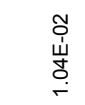 & 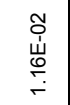 & 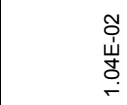 & 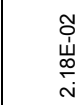 & 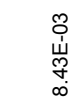 & $\begin{array}{l}\stackrel{N}{\mathcal{H}} \\
\stackrel{\mathrm{m}}{\mathrm{m}}\end{array}$ \\
\hline 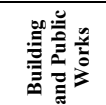 & 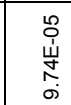 & 旁 & 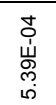 & 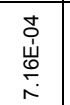 & 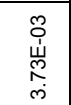 & 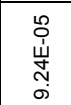 & 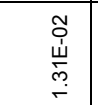 & 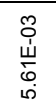 & 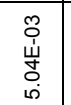 & $\begin{array}{l}\stackrel{\infty}{0} \\
\stackrel{\leftrightarrow}{\varpi} \\
\stackrel{\infty}{\infty}\end{array}$ & 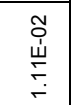 & $\begin{array}{l}\stackrel{8}{+} \\
\stackrel{\leftrightarrow}{山} \\
\stackrel{\leftrightarrow}{+}\end{array}$ & $\begin{array}{l}\stackrel{0}{0} \\
\stackrel{\leftrightarrow}{W} \\
\stackrel{\leftrightarrow}{\leftarrow}\end{array}$ & 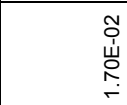 & 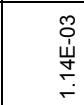 & 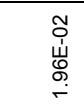 & 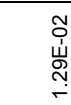 \\
\hline & 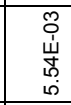 & 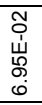 & 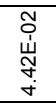 & 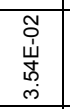 & 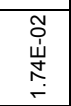 & 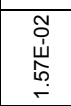 & 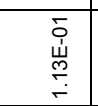 & 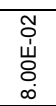 & 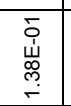 & 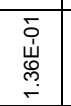 & 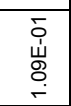 & 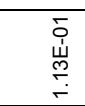 & 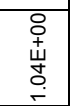 & 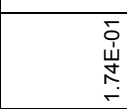 & 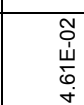 & 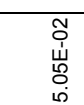 & 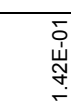 \\
\hline 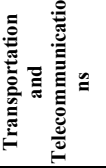 & 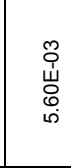 & 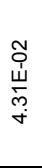 & 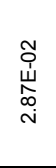 & 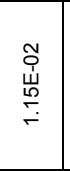 & 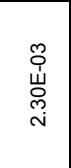 & 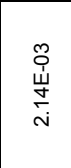 & 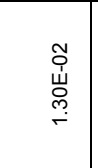 & 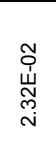 & 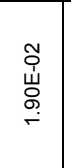 & 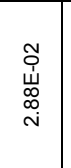 & 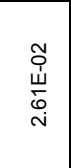 & 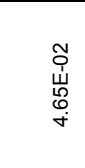 & 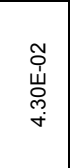 & 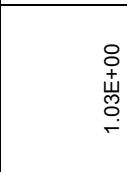 & 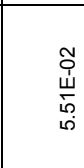 & 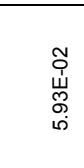 & 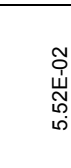 \\
\hline 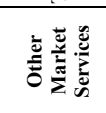 & 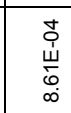 & 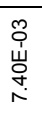 & 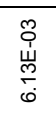 & 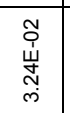 & 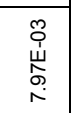 & 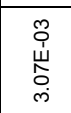 & \begin{tabular}{l} 
ָे \\
$\stackrel{\sim}{\sim}$ \\
\multirow{N}{N}{}
\end{tabular} & 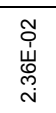 & 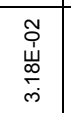 & 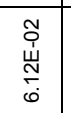 & $\begin{array}{l}\underset{N}{N} \\
\underset{N}{N} \\
\dot{\omega}\end{array}$ & 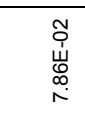 & 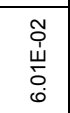 & 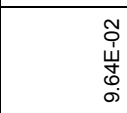 & 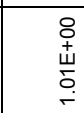 & 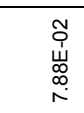 & 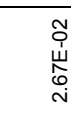 \\
\hline 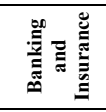 & 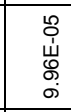 & 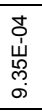 & 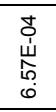 & 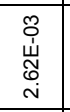 & 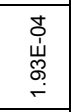 & 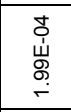 & 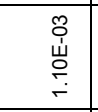 & 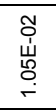 & 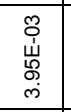 & 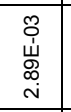 & 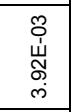 & 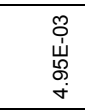 & 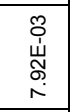 & 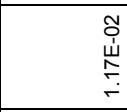 & 罳 & 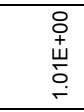 & 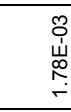 \\
\hline 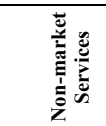 & $\begin{array}{l}\stackrel{8}{0} \\
\text { 山े } \\
\text { ه. } \\
0\end{array}$ & $\begin{array}{l}\stackrel{8}{+} \\
\text { ठे } \\
\text {. }\end{array}$ & $\begin{array}{l}\stackrel{8}{+} \\
\text { ثे } \\
\text {. }\end{array}$ & $\begin{array}{l}\stackrel{8}{+} \\
\dot{+} \\
\stackrel{\leftrightarrow}{0} \\
0 \\
0\end{array}$ & 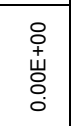 & $\begin{array}{l}\stackrel{8}{+} \\
\text { 山े } \\
\stackrel{0}{0} \\
0\end{array}$ & $\begin{array}{l}\stackrel{8}{+} \\
\stackrel{+}{山} \\
\stackrel{0}{0} \\
0\end{array}$ & $\begin{array}{l}\stackrel{8}{+} \\
\stackrel{4}{0} \\
\stackrel{0}{0}\end{array}$ & $\begin{array}{l}\stackrel{8}{+} \\
\dot{山} \\
\stackrel{\Delta}{0} \\
0\end{array}$ & $\begin{array}{l}\stackrel{8}{+} \\
\text { 山े } \\
\stackrel{0}{0} \\
\stackrel{0}{0}\end{array}$ & $\begin{array}{l}\stackrel{8}{+} \\
\text { ڤे } \\
\stackrel{0}{0}\end{array}$ & $\begin{array}{l}\stackrel{8}{+} \\
\text { 山े } \\
\stackrel{\leftrightarrow}{0} \\
0\end{array}$ & $\begin{array}{l}\stackrel{8}{+} \\
\text { 山े } \\
\stackrel{0}{0} \\
0\end{array}$ & 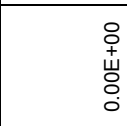 & 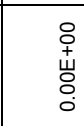 & $\begin{array}{l}\stackrel{8}{+} \\
\text { 山े } \\
0 \\
0\end{array}$ & $\begin{array}{l}\stackrel{8}{+} \\
+ \\
\stackrel{4}{\circ}\end{array}$ \\
\hline & 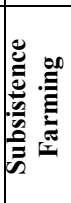 & $\stackrel{\mathscr{E}}{\stackrel{\mathscr{E}}{\varkappa}}$ & 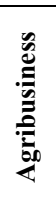 & : & 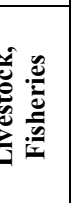 & 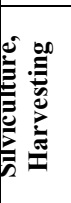 & 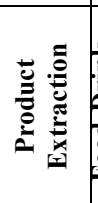 & & 要 & ن. & 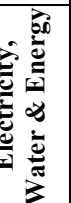 & 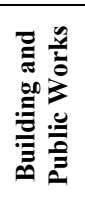 & $\stackrel{\Xi}{\Xi}$ & 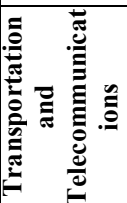 & 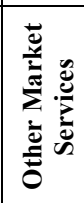 & 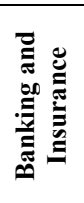 & 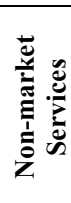 \\
\hline
\end{tabular}




\section{APPENDIX B: MATERIALS LISTS, I/O MODELS FOR EACH INTERVENTION}

For source-level interventions, the totals shown are for a single unit of an intervention. These totals were multiplied by a factor of 1.5 to calculate the values reported in the study. The totals shown for POU treatments are for a single household. These totals were multiplied by 52.4 to calculate the values reported in the study. Non-market goods for which no material energy was calculated (i.e., sand and gravel) are not listed. Embodied energies may not sum to totals due to rounding

Table 7: Materials list for an improved well

\begin{tabular}{|c|c|c|c|c|}
\hline Material & Total Price (FCFA) & Origin & Sector Assignment & Embodied Energy (MJ) \\
\hline Cement & 82,500 & Senegal & Process Data & 1,760 \\
\hline \#8 Rebar & 8,320 & China & Metal Products & 552 \\
\hline Metal Door & 10,500 & China & Metal Products & 696 \\
\hline Paint & 1,250 & United States & Paint And Coating Manufacturing & 44 \\
\hline \multirow[t]{2}{*}{ Bailing Wire } & 25 & China & Metal Products & 2 \\
\hline & & & Total: & 3,053 \\
\hline
\end{tabular}


Table 8: Materials list for a rope pump

\begin{tabular}{|c|c|c|c|c|}
\hline Material & $\begin{array}{l}\text { Total Price } \\
\text { (CFA) }\end{array}$ & Origin & Sector Assignment & Embodied Energy \\
\hline Angle Iron \#40 & 1,375 & China & Metal Products & 91 \\
\hline \multicolumn{5}{|l|}{ 20/27 Galvanized } \\
\hline Pipe & 267 & China & Metal Products & 18 \\
\hline 15/21 Steel Pipe & 2,850 & China & Metal Products & 189 \\
\hline Tire & 500 & \multicolumn{2}{|c|}{ Local Recycled } & 0 \\
\hline \#12 Rebar & 1,155 & China & Metal Products & 77 \\
\hline \#8 Rebar & 583 & China & Metal Products & 39 \\
\hline 10/10 Sheet Metal & 9,500 & China & Metal Products & 631 \\
\hline \#20 Flat Iron & 1,500 & China & Metal Products & 100 \\
\hline \#20 Angle Iron & 2,500 & China & Metal Products & 166 \\
\hline \#8 Threaded Rod & 1,500 & China & Metal Products & 100 \\
\hline \#6 Bolts & 500 & China & Metal Products & 33 \\
\hline Grease Paint & 2,500 & United States & $\begin{array}{l}\text { Paint And Coating } \\
\text { Manufacturing }\end{array}$ & 87 \\
\hline Welding Rod & 3,500 & China & $\begin{array}{l}\text { Other Non-Metallic Mineral } \\
\text { Products }\end{array}$ & 402 \\
\hline PVC Pipe, $40 \mathrm{~mm}$ & 198 & United States/Europe & Plastics Pipe Manufacturing & 10 \\
\hline Rope & 15,000 & \multicolumn{2}{|c|}{ Local Recycled } & 0 \\
\hline Glue & 5,000 & China & Synthetic Chemicals & 469 \\
\hline Labor & 20,000 & Mali & Building And Public Works & 7 \\
\hline PVC Pipe, $25 \mathrm{~mm}$ & 15,938 & Europe/United States & Plastics Pipe Manufacturing & 804 \\
\hline Cement & 82,500 & Senegal & Process Data & 1,760 \\
\hline \#8 Rebar & 8,320 & China & Metal Products & 552 \\
\hline Metal Door & 10,500 & China & Metal Products & 696 \\
\hline Paint & 1,250 & United States & Paint And Coating Mfg & 44 \\
\hline Bailing Wire & 2,500 & China & Metal Products & 2 \\
\hline & & & Total & 6,275 \\
\hline
\end{tabular}


Table 9: Materials list for an India Mark II hand pump

\begin{tabular}{rclr}
\hline Material/Service & Total Price (CFA) & Origin & \multicolumn{2}{l}{$\begin{array}{l}\text { Embodied Energy } \\
\text { (MJ) }\end{array}$} \\
\hline PVC Pipe, 4.5" & 900,000 & Europe/ United States & Plastics Pipe And Pipe Fitting Manufacturing \\
\hline PVC Screen & 200,000 & Europe/ United States & Plastics Pipe And Pipe Fitting Manufacturing \\
\hline PVC End Cap & 10,000 & Europe/ United States & Plastics Pipe And Pipe Fitting Manufacturing \\
\hline Sealing Grout & 90,000 & Senegal & Cement Process Data \\
\hline Metal Pump Head & 280,000 & India/ China & Metal Products \\
\hline Rising Main Installation & 885,000 & China & Metal Products \\
\hline Cement & 2,100 & Senegal & Cement Process Data \\
\hline Service Fee & $1,500,000$ & Mali & Building And Public Works \\
\hline Drill 10" Borehole & 200,000 & Local & Building And Public Works \\
\hline Drill 7" Borehole & 720,000 & Mali & Building And Public Works \\
\hline Footvalve Installation & 10,000 & Mali & Building And Public Works \\
\hline Backfill & 50,000 & Mali & Building And Public Works \\
\hline Well Development & 80,000 & Mali & Building And Public Works \\
\hline Recovery Test Monitoring & 270,000 & Mali & Building And Public Works \\
\hline Pump Installation & 275,000 & Mali & Building And Public Works \\
\hline
\end{tabular}


Table 10: Materials list for a solar pump

\begin{tabular}{|c|c|c|c|c|}
\hline Material & $\begin{array}{l}\text { Total Price } \\
\text { (CFA) }\end{array}$ & Origin & Sector Assignment & $\begin{array}{l}\text { Embodied } \\
\text { Energy }\end{array}$ \\
\hline Cement & 77,490 & Senegal & Process Data & 2,446 \\
\hline Bailing Wire & 1,858 & China & Metal Products & 123 \\
\hline Chicken Wire & 13,776 & China & Metal Products & 915 \\
\hline 20/27 Galvanized Pipe & 1,333 & China & Metal Products & 89 \\
\hline 15/21 Steel Pipe & 200 & China & Metal Products & 13 \\
\hline 20/27 Water Tap & 4,800 & China & Metal Products & 319 \\
\hline Corrugated Steel & 16,800 & China & Metal Products & 1,115 \\
\hline PVC Pipe, 4.5" & 900,000 & Europe/US & Plastics Pipe And Pipe Fitting Manufacturing & 45,383 \\
\hline PVC Screen & 200,000 & Europe/US & Plastics Pipe And Pipe Fitting Manufacturing & 10,085 \\
\hline PVC End Cap & 10,000 & Europe/US & Plastics Pipe And Pipe Fitting Manufacturing & 504 \\
\hline Sealing Grout & 90,000 & Senegal & Cement Process Data & 2,850 \\
\hline Rising Main & 885,000 & China & Metal Products & 58,750 \\
\hline PV-Compatible Pump & 705,000 & $\begin{array}{l}\text { United } \\
\text { States }\end{array}$ & Pump And Pump Equipment Manufacturing & 12,700 \\
\hline Solar Panels & $2,820,000$ & $\begin{array}{l}\text { United } \\
\text { States }\end{array}$ & $\begin{array}{l}\text { Semiconductor And Related Device } \\
\text { Manufacturing }\end{array}$ & 45,300 \\
\hline 20/27 Galvanized Pipe & 3,000 & China & Metal Products & 199 \\
\hline 20/27 Galvanized Elbow & 500 & China & Metal Products & 33 \\
\hline Service Fee & $1,500,000$ & Local & Building And Public Works & 499 \\
\hline Drill 10" Borehole & 200,000 & Local & Building And Public Works & 67 \\
\hline Drill 7" Borehole & 720,000 & Local & Building And Public Works & 239 \\
\hline Footvalve Installation & 10,000 & Local & Building And Public Works & 3 \\
\hline Backfill & 50,000 & Local & Building And Public Works & 17 \\
\hline Well Development & 80,000 & Local & Building And Public Works & 27 \\
\hline \multirow[t]{2}{*}{ Recovery Test Monitoring } & 270,000 & Local & Building And Public Works & 90 \\
\hline & & & Total & 181,765 \\
\hline
\end{tabular}


Table 11: Materials list for a biosand filter

\begin{tabular}{|c|c|c|c|c|}
\hline Material & $\begin{array}{l}\text { Total } \\
\text { Price } \\
\text { (CFA) } \\
\end{array}$ & Origin & Sector assignment & $\begin{array}{l}\text { Embodied } \\
\text { Energy (MJ) }\end{array}$ \\
\hline Cement & 1,500 & Senegal & Process Data & 48 \\
\hline 1/2" PVC Elbow & 2,250 & Europe/US & Plastics Pipe And Pipe Fittings Manufacturing & 113 \\
\hline \multirow[t]{2}{*}{ 1/2" PCV Pipe } & 400 & Europe/US & Plastics Pipe And Pipe Fittings Manufacturing & 20 \\
\hline & & & Total & 181 \\
\hline
\end{tabular}

Table 12: Materials list for a ceramic filter. Replaced once over 10 years

\begin{tabular}{llll}
\hline Material & Origin & Sector Assignment & Embodied Energy (MJ) \\
\hline Clay Filter & Mali & Process Data & $\mathbf{2 , 0 3 6}$ \\
\hline
\end{tabular}

Table 13: Materials list for chlorination. Bottle purchased 335 times over 10 years

\begin{tabular}{|c|c|c|c|c|}
\hline Material & $\begin{array}{l}\text { Total Price } \\
\text { (CFA) }\end{array}$ & Origin & Sector Assignment & $\begin{array}{l}\text { Embodied Energy } \\
\text { (MJ) }\end{array}$ \\
\hline 250ml Bottle, 12 Degree & 300 & Local & Other Manufactured Goods & 2,098 \\
\hline
\end{tabular}

Table 14: Materials list for boiling. Quantity calculated over 10 years

\begin{tabular}{lllr}
\hline Material & Origin & Sector Assignment & Embodied Energy (MJ) \\
\hline Firewood & Mali & Process Data & $\mathbf{1 7 1 , 8 7 6 , 7 7 4}$ \\
\hline
\end{tabular}


APPENDIX C: LIST OF HUMAN ENERGY EXPENDED CONSTRUCTING AND OPERATING INTERVENTIONS

Table 15: Human energy expended constructing and using an improved well

\begin{tabular}{|c|c|c|c|c|c|c|c|}
\hline Labor & $\begin{array}{c}\text { Laborers } \\
\text { Per } \\
\text { Household } \\
\end{array}$ & Households & $\begin{array}{c}\text { Activity Analogue Or } \\
\text { Category }\end{array}$ & PAR & $\begin{array}{l}\text { Hours } \\
\text { Per Day }\end{array}$ & Days & $\begin{array}{l}\text { Energy } \\
\text { Expended } \\
\text { (MJ) }\end{array}$ \\
\hline $\begin{array}{l}\text { Expanding Well } \\
\text { Mouth }\end{array}$ & 3 & 1 & Digging & 5.6 & 8 & 2.5 & 84 \\
\hline Making Bricks & 3 & 1 & Making Mud Bricks & 3 & 8 & 2 & 29 \\
\hline $\begin{array}{l}\text { Sawing And } \\
\text { Bending Rebar }\end{array}$ & 3 & 1 & 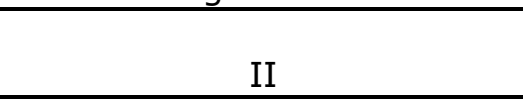 & 3.3 & 4 & 1 & 8 \\
\hline $\begin{array}{l}\text { Pouring Concrete } \\
\text { Foundation } \\
\end{array}$ & 4 & 1 & III & 4.81 & 3.5 & 1 & 16 \\
\hline Laying Bricks & 4 & 1 & III & 4.81 & 4 & 1 & 18 \\
\hline Bending Rebar & 3 & 1 & II & 3.3 & 4 & 1 & 8 \\
\hline Casting Well Top & 4 & 1 & II & 3.3 & 3.5 & 1 & 10 \\
\hline $\begin{array}{l}\text { Mortaring Well } \\
\text { Top }\end{array}$ & 3 & 1 & II & 3.3 & 3 & 1 & 6 \\
\hline $\begin{array}{l}\text { Compact And } \\
\text { Grade For Apron }\end{array}$ & 4 & 1 & III & 4.81 & 4 & 1 & 18 \\
\hline $\begin{array}{l}\text { Casting Well } \\
\text { Apron }\end{array}$ & 4 & 1 & II & 3.3 & 4 & 1 & 11 \\
\hline $\begin{array}{l}\text { Collecting/Sieving } \\
\text { Gravel And Sand }\end{array}$ & 2 & 1 & Digging & 5.6 & 5.15 & 1 & 14 \\
\hline Collect Water & 1 & 52.4 & Collecting Water & 4.5 & 0.5 & 3652.5 & 100595 \\
\hline Transport Water & 1 & 52.4 & Walking With $25-30 \mathrm{Kg}$ Load & 3.9 & 0.2 & 3652.5 & 27370 \\
\hline & & & & & & Total: & 128190 \\
\hline
\end{tabular}


Table 16: Human energy expended constructing and using a rope pump

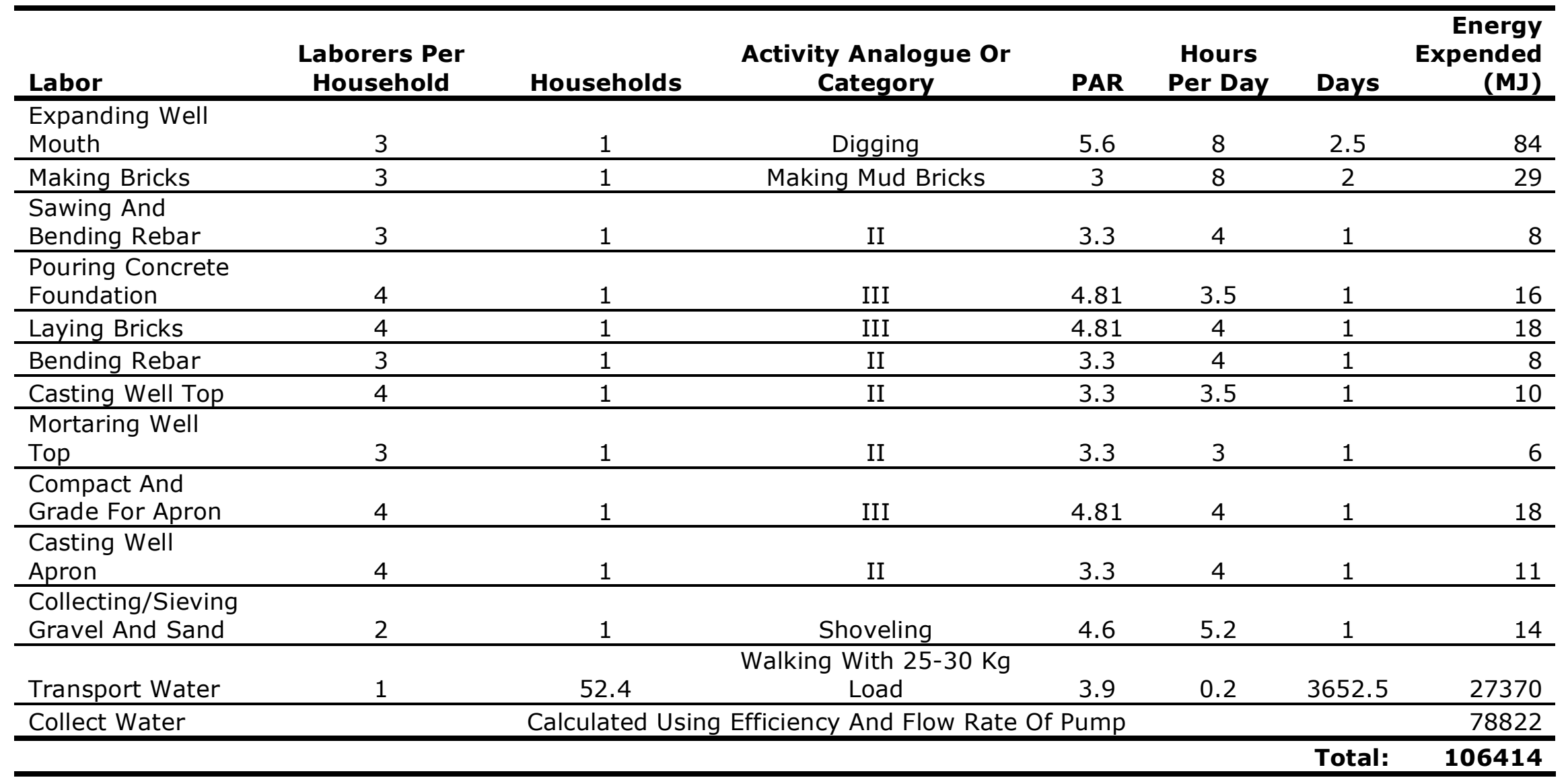


Table 17: Human energy expended constructing and using an India Mark II hand pump

\begin{tabular}{|c|c|c|c|c|c|c|c|}
\hline Labor & $\begin{array}{c}\text { Laborers Per } \\
\text { Household }\end{array}$ & Households & Activity Analogue & PAR & $\begin{array}{c}\text { Hours Per } \\
\text { Day }\end{array}$ & Days & $\begin{array}{r}\text { Energy } \\
\text { Expended } \\
(\mathrm{MJ}) \\
\end{array}$ \\
\hline Pumping Water & \multicolumn{6}{|c|}{ Calculated Using Efficiency And Flow Rate Of Pump } & 10281 \\
\hline Walking With 25-30 & 1 & 52.4 & $\mathrm{Kg}$ Load & 3.9 & 0.2 & 3652.5 & 27370 \\
\hline \multirow{2}{*}{\multicolumn{8}{|c|}{$\begin{array}{l}\text { Collecting/Sieving } \\
\text { Gravel And Sand }\end{array}$}} \\
\hline & 2 & 1 & Digging & 5.6 & 0.26 & 1 & 0.73 \\
\hline
\end{tabular}

Table 18: Human energy expended constructing and using a solar pump

\begin{tabular}{|c|c|c|c|c|c|c|c|}
\hline Labor & $\begin{array}{l}\text { Laborers Per } \\
\text { Household }\end{array}$ & Households & $\begin{array}{c}\text { Activity Analogue } \\
\text { Or Category }\end{array}$ & PAR & $\begin{array}{c}\text { Hours Per } \\
\text { Day }\end{array}$ & Days & $\begin{array}{r}\text { Energy } \\
\text { Expended } \\
(\mathrm{MJ})\end{array}$ \\
\hline $\begin{array}{l}\text { Collecting/Sieving } \\
\text { Gravel And Sand }\end{array}$ & 2 & 1 & Shoveling & 4.6 & 5.7 & 1 & 13 \\
\hline $\begin{array}{l}\text { Constructing } \\
\text { Tank }\end{array}$ & 5 & 1 & $\begin{array}{c}\text { II } \\
\text { Walking With 25-30 }\end{array}$ & 3.3 & 8 & 3 & 84 \\
\hline Transport Water & 1 & 52.4 & $\mathrm{Kg}$ Load & 3.9 & 0.2 & 3652.5 & 27370 \\
\hline
\end{tabular}


Table19: Human energy expended constructing and using a biosand filter

\begin{tabular}{|c|c|c|c|c|c|c|c|}
\hline Labor & $\begin{array}{l}\text { Laborers Per } \\
\text { Household }\end{array}$ & Households & Activity Analogue & PAR & $\begin{array}{l}\text { Hours } \\
\text { Per Day }\end{array}$ & Days & $\begin{array}{r}\text { Energy } \\
\text { Expended } \\
(\mathrm{MJ})\end{array}$ \\
\hline \multicolumn{8}{|l|}{ Collecting/Sieving } \\
\hline Gravel And Sand & 2 & 52.4 & Shoveling & 4.6 & 0.193 & 1 & 22 \\
\hline \multirow{2}{*}{ Collect Water } & 1 & 52.4 & Collecting Water & 4.5 & 0.5 & 3652.5 & 100595 \\
\hline & & & Walking With $25-30 \mathrm{Kg}$ & & & & \\
\hline \multirow[t]{2}{*}{ Transport Water } & 1 & 52.4 & Load & 3.9 & 0.2 & 3652.5 & 27370 \\
\hline & & & & & & Total: & 127987 \\
\hline
\end{tabular}

Table20: Human energy expended using a ceramic filter

\begin{tabular}{|c|c|c|c|c|c|c|c|}
\hline Labor & $\begin{array}{c}\text { Laborers Per } \\
\text { Household }\end{array}$ & Households & Activity Analogue & PAR & $\begin{array}{c}\text { Hours Per } \\
\text { Day }\end{array}$ & Days & $\begin{array}{r}\text { Energy } \\
\text { Expended } \\
(\mathrm{MJ}) \\
\end{array}$ \\
\hline Collect Water & 1 & 52.4 & Collecting Water & 4.5 & 0.5 & 3652.5 & 100594 \\
\hline & & & & & & Total: & 127965 \\
\hline
\end{tabular}


Table 21: Human energy expended using chlorine bleach

\begin{tabular}{|c|c|c|c|c|c|c|c|}
\hline Labor & $\begin{array}{c}\text { Laborers Per } \\
\text { Household }\end{array}$ & Households & Activity Analogue & PAR & $\begin{array}{c}\text { Hours Per } \\
\text { Day }\end{array}$ & Days & $\begin{array}{r}\text { Energy } \\
\text { Expended } \\
(\mathrm{MJ})\end{array}$ \\
\hline Collect Water & 1 & 52.4 & Collecting Water & 4.5 & 0.5 & 3652.5 & 100594 \\
\hline Water & & & & & & Total: & 127965 \\
\hline
\end{tabular}


Table 22: Human energy expended using firewood to boil water

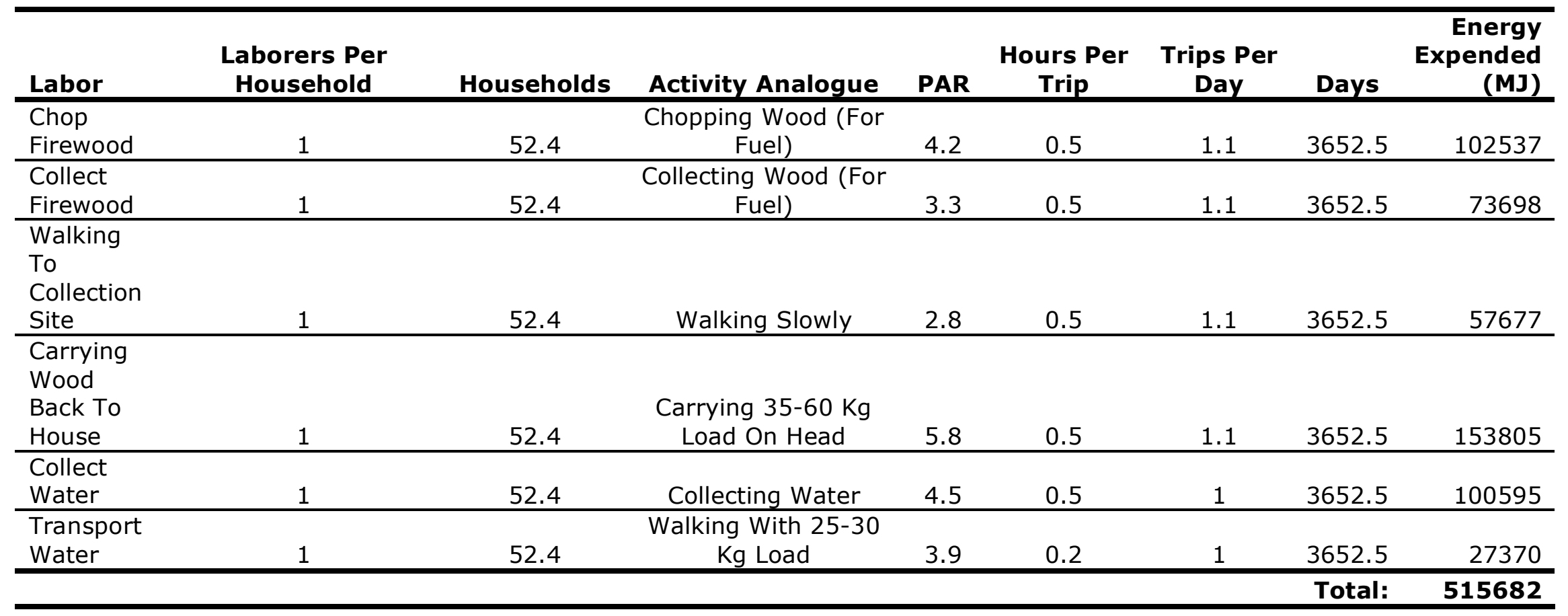

